Prepared for the U.S. Department of Energy

under Contract DE-AC05-76RL01830

\title{
Assessment of the Species \\ Composition, Densities, and \\ Distribution of Native Freshwater \\ Mussels along the Benton County \\ Shoreline of the Hanford Reach, \\ Columbia River, 2004
}
RP Mueller
GK Turner
BL Tiller
ID Welch
MD Bleich

January 2011

\section{Pacific Northwest}

NATIONAL LABORATORY

Proudly Operated by Battelle Since 1965 


\title{
DISCLAIMER
}

This report was prepared as an account of work sponsored by an agency of the United States Government. Neither the United States Government nor any agency thereof, nor Battelle Memorial Institute, nor any of their employees, makes any warranty, express or implied, or assumes any legal liability or responsibility for the accuracy, completeness, or usefulness of any information, apparatus, product, or process disclosed, or represents that its use would not infringe privately owned rights. Reference herein to any specific commercial product, process, or service by trade name, trademark, manufacturer, or otherwise does not necessarily constitute or imply its endorsement, recommendation, or favoring by the United States Government or any agency thereof, or Battelle Memorial Institute. The views and opinions of authors expressed herein do not necessarily state or reflect those of the United States Government or any agency thereof.

\author{
PACIFIC NORTHWEST NATIONAL LABORATORY \\ operated by \\ BATTELLE \\ for the \\ UNITED STATES DEPARTMENT OF ENERGY \\ under Contract DE-AC05-76RL01830
}

\author{
Printed in the United States of America \\ Available to DOE and DOE contractors from the \\ Office of Scientific and Technical Information, \\ P.O. Box 62, Oak Ridge, TN 37831-0062; \\ ph: (865) 576-8401 \\ fax: $(865) 576-5728$ \\ email: reports@adonis.osti.gov

\footnotetext{
Available to the public from the National Technical Information Service,

U.S. Department of Commerce, 5285 Port Royal Rd., Springfield, VA 22161

ph: (800) 553-6847

fax: $(703) 605-6900$

email: orders@ntis.fedworld.gov

online ordering: http://www.ntis.gov/ordering.htm
}

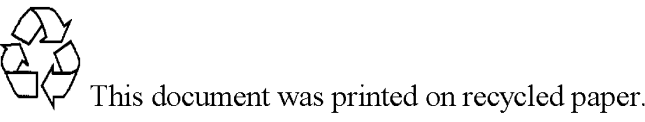

(9/2003) 


\title{
Assessment of the Species Composition, Densities, and Distribution of Native Freshwater Mussels along the Benton County Shoreline of the Hanford Reach, Columbia River, 2004
}

\author{
RP Mueller \\ BL Tiller ${ }^{1}$ \\ GK Turner ${ }^{2}$ \\ MD Bleich ${ }^{3}$ \\ ID Welch ${ }^{3}$
}

January 2011

Prepared for

the U.S. Department of Energy

under Contract DE-AC05-76RL01830

Pacific Northwest National Laboratory

Richland, Washington 99352

\footnotetext{
${ }^{1}$ Environmental Assessment Services, Richland, Washington.

${ }^{2}$ Grant County PUD, Ephrata, Washington.

${ }^{3}$ HDR Engineering, Bellevue, Washington.
} 


\section{Summary}

The Hanford Reach of the Columbia River is the last unimpounded section of the river and contains substrate characteristics (cobble, gravel, sand/silt) suitable for many of the native freshwater mussels known to exist in the Pacific Northwest. Information concerning the native mussel species composition, densities, and distributions in the mainstem of the Columbia River is limited. Under funding from the U.S. Department of Energy Richland Operations Office (DOE-RL), Pacific Northwest National Laboratory (PNNL) conducted an assessment of the near-shore habitat on the Hanford Reach. Surveys conducted in 2004 as part of the Ecological Monitoring and Compliance project documented several species of native mussels inhabiting the near-shore habitat of the Hanford Reach. Findings reported here may be useful to resource biologists, ecologists, and DOE-RL to determine possible negative impacts to native mussels from ongoing near-shore remediation activities associated with Hanford Site cleanup.

The objective of this study was to provide an initial assessment of the species composition, densities, and distribution of the freshwater mussels (Margaritiferidae and Unionidae families) that exist in the Hanford Reach. The 90-km stretch of the Columbia River between Priest Rapids Dam and the city of Richland was surveyed at selected points in areas where mussel beds were known or suspected to exist and in areas near the Hanford Site decommissioned reactor facilities. PNNL researchers conducted underwater surveys by snorkeling to survey 52 transects at water depths of 1 to $2 \mathrm{~m}$ below the low-water mark, an area that collectively comprised $28,482 \mathrm{~m}^{2}$ of river bottom. At each sampling point, the mussel species composition and the number of individuals observed were recorded.

Researchers observed and measured 201 live native mussel specimens. Mussel density estimated from these surveys is summarized in this report with respect to near-shore habitat characteristics including substrate size, substrate embeddedness, relative abundance of aquatic vegetation, and large-scale geomorphic/hydrologic characteristics of the Hanford Reach.

Three species belonging to the Unionidae family (Anodonta spp.) were common in habitats in the Hanford Reach that were dominated by sand/silt substrates. Habitat factors that appear to affect mussel densities and diversity included dominant and subdominant substrate sizes, substrate embeddedness, and the relative amount of submerged aquatic vegetation (macrophytes). Most of the lower sections of the Hanford Reach contained habitat more suitable for mussels (i.e., slower water velocities and smaller substrate size) compared to the upper sections of the Hanford Reach where mussel distributions were more limited. The highest Anodonta densities were found in areas where the aquatic vegetation was sparse but present.

Two species, the western floater (A. kennerlyi) and the Oregon floater (A. oregonensis), were found in virtually all substrate types sampled (sand/silt, pebble, and cobble) where substrates included at least $50 \%$ fine material. Low to medium densities $\left(0.5\right.$ to 2.5 mussels $\left./ 100 \mathrm{~m}^{2}\right)$ of the western floater and Oregon floater were identified throughout approximately $60 \%$ of the Hanford Reach.

The California floater (A. californiensis), listed as a federal species of concern in the United States, was found in a few areas where river velocities were very low and the substrate consisted largely of fine sands/silt. These represent slough/backwater channels that comprise approximately $1.5 \%$ of the riverine habitats along the Hanford Reach. 
Several shells of the western pearlshell mussel (Margaritafera falcata) were found at 2 of the 52 sites sampled. These specimens appeared to have recently died (as indicated by shell coloration and hinge ligament integrity). However, the species appears to be largely absent from its historical range indicated by archeological records. Archeological evidence along the Hanford Reach has indicated that extensive beds of pearlshell mussel once existed at the White Bluffs Slough.

Of the four species of native mussels found in the Hanford Reach, the western and Oregon floaters were the most abundant across the three river classes that represent the larger scale geomorphology-the symmetrical riverine channels, island-adjacent channels, and slough/backwater areas. The California floater was next most abundant. The California and western floaters were found most commonly in the sloughs or backwater areas. Based on the sampling results, the western pearlshell mussel appears to be extirpated from the Hanford Reach. 


\section{Acknowledgments}

The authors thank James Bernard for assisting in collections and data summaries, and Janelle Downs, Ted Poston, and Roger Dirkes for providing technical review. Andrea Currie provided editorial support. 


\section{Acronyms and Abbreviations}

$\begin{array}{ll}\text { BP } & \text { before present } \\ \text { DOE } & \text { U.S. Department of Energy } \\ \text { DOE-RL } & \text { DOE Richland Operations Office } \\ \mathrm{km} & \text { kilometer(s) } \\ \mathrm{m} & \text { meter(s) } \\ \mathrm{mm} & \text { millimeter(s) } \\ \text { PNNL } & \text { Pacific Northwest National Laboratory } \\ \mathrm{RM} & \text { river mile(s) } \\ \mathrm{s} & \text { second(s) } \\ \mathrm{spp} . & \text { species }\end{array}$




\section{Contents}

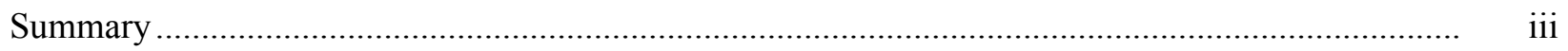

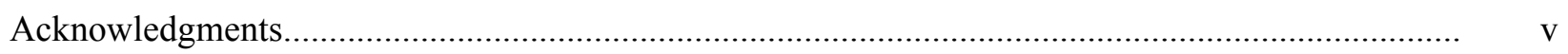

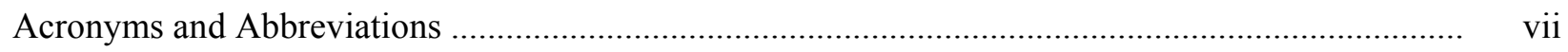

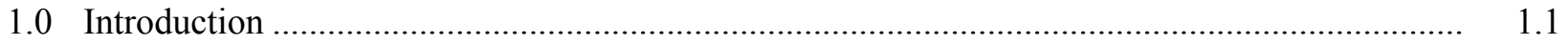

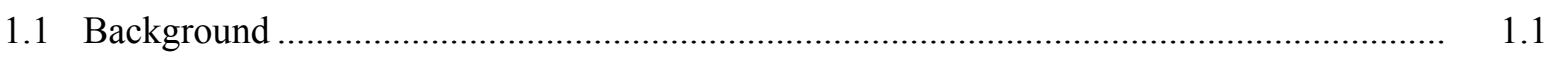

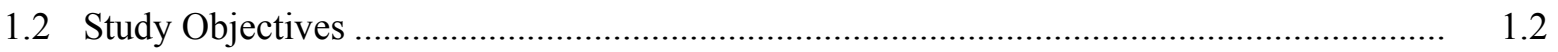

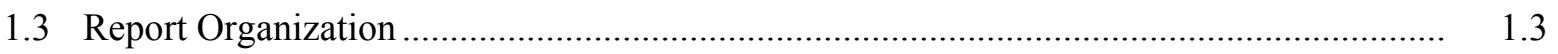

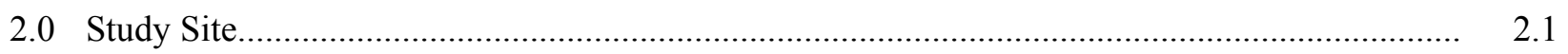

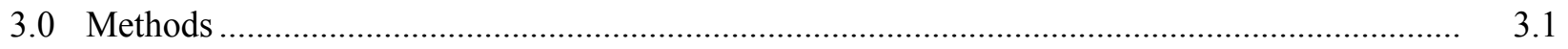

3.1 Survey Techniques for Species Composition, Density, and Demographics ..................... 3.1

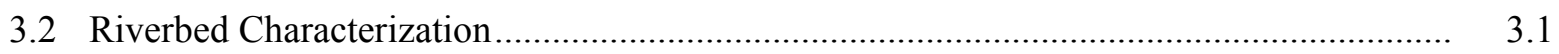

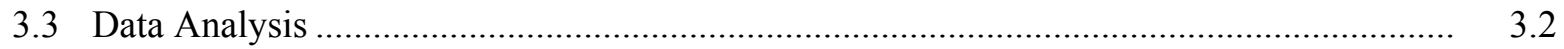

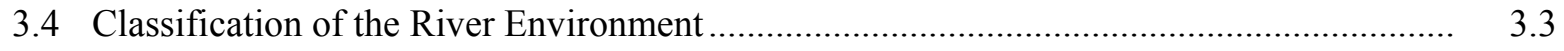

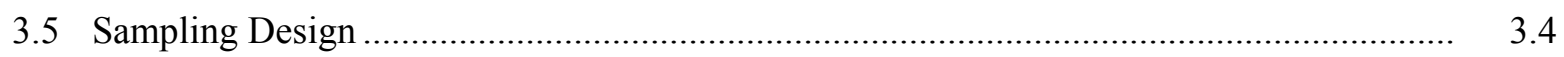

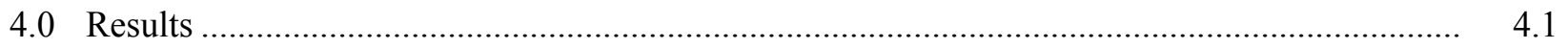

4.1 Species Composition and Relative Abundance Estimates ............................................ 4.1

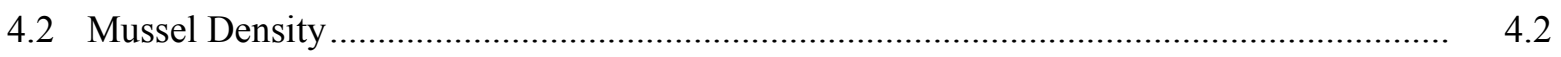

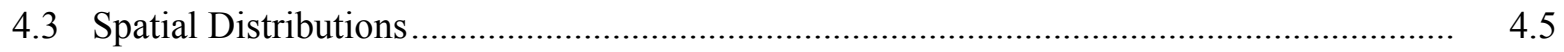

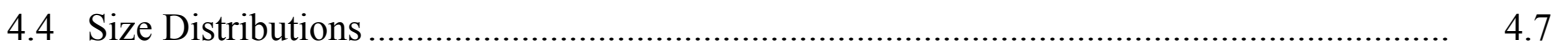

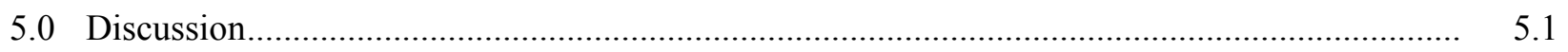

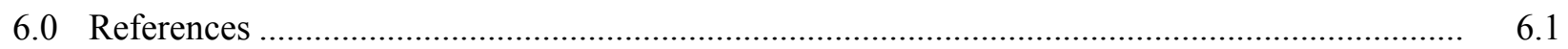

Appendix - Anodonta Sightings in the Hanford Reach, 2004 ..................................................... A.1 


\section{Figures}

2.1 The Hanford Reach of the Columbia River in south-central Washington State ......................... 2.1

3.1 The four embeddedness categories as described in Table 3.2 ................................................ 3.3

3.2 Sites surveyed for native mussels along the Benton County shoreline of the Hanford Reach in 2004 .....

4.1 Mussel species observed along the Hanford Reach during 2004..

4.2 Average shell length-to-depth ratios of Anodonta species measured along the Hanford Reach in 2004

4.3 Relative abundance of native mussels found along the Hanford Reach during 2004.

4.4 Densities of native mussels relative to substrate embeddedness for all 52 transects

4.5 Densities of native mussels relative to dominant substrate for all 52 transects

4.6 Densities of native mussels based upon relative abundance of macrophytic vegetation for all 52 transects.

4.7 Mean density of Anodonta spp. relative to river channel classification

4.8 Estimated relative abundance and distribution of native mussels along the Hanford Reach, 2004

4.9 Size distribution of shell length of Anodonta species collected and measured along the Hanford Reach during 2004.

\section{Tables}

3.1 Dominant and subdominant substrate classifications used during the 2004 native mussel surveys

3.2 Classifications of substrate embeddedness measured during the 2004 native mussel surveys

3.3 General river classes between Richland and the Vernita Bridge and the number of transects selected and surveyed for native mussels during 2004. 


\subsection{Introduction}

Freshwater mussels (Bivalvia, Unionoida) are an important component of a healthy stream or river ecosystem. In addition, mussels often are used by various agencies to monitor environmental quality, including trends of chemical contamination (Rosenberg and Resh 1992). However, native freshwater mussel populations are declining rapidly, both globally and in the United States (Lydeard et al. 2004). Mussels are currently one of the most endangered groups of animals in North America. Over the past 150 years in the Pacific Northwest, native mussels have been affected adversely by manmade disturbances including land-use practices, dam building, pollution, introduced species, and reductions or loss of anadromous salmonids to watersheds. The life cycle of all freshwater mussels includes a period during which mussels are dependent on a fish host. The fish host for Anodonta species is not specific and is unknown for most species (Nedeau et al. 2009).

Current knowledge of mussel populations in the Columbia River is limited, and it is speculated that the range of native mussels is restricted compared to historical records (Frest and Johannes 1995). The Hanford Reach contains the last unimpounded stretch of the Columbia River and retains substrate characteristics (cobble, gravel, sand/silt) assumed to be suitable for a number of native freshwater mussels known to exist in the Pacific Northwest. Data describing mussel species composition, densities, and other attributes such as demographics are needed to aid in assessments of environmental quality of a specific river ecosystem.

The study described in this report was funded by the U.S. Department of Energy Richland Operations Office (DOE-RL) and conducted as part of the Pacific Northwest National Laboratory (PNNL) Ecological Monitoring and Compliance project. The study findings can be used by resource biologists, ecologists, and DOE-RL to determine possible negative impacts to native mussels from ongoing near-shore remediation activities at the Hanford Site.

\subsection{Background}

A limited number of native mussel and gastropod surveys have been conducted on the Columbia River (Coutant and Becker 1970; Neitzel and Frest 1989, 1993). Helmstetler and Cowles (2008) conducted a mollusk population survey in 2006 in the mid-Columbia River including the Hanford Reach. This study found Anodonta species at two locations at densities of 0.01 and 0.66 live mussel $/ \mathrm{m}^{2}$. A few small-scale mussel surveys have been done in the Hanford Reach (Frest and Johannes 1993). Other surveys have been carried out at the 100-N Area shoreline in association with risk assessments conducted at the Hanford Site (DOE-RL 2006). A comprehensive study was performed on the distribution and density of Asiatic clams inhabiting the Hanford Reach in 2002 (Turner 2004). Stark (2001) found only rare occurrences of mussels during a study of macroinvertebrates on the Hanford Reach at three locations near river miles (RM) 368, 370.5, and 379 .

Thirteen species of freshwater bivalves (twelve native, one introduced) have been reported historically in the mainstem Columbia River (Frest and Johannes 1993). Diversity is generally highest in the lowermost $161 \mathrm{~km}$ of the river and lowest near the river's origin (Frest and Johannes 1993). Many other taxa are found in tributary streams. Seven native mussel species have been identified in Washington State, six of which occurred historically in the mainstem of the Columbia River - the California floater (A. californiensis), western floater (A. kennerlyi), Oregon floater (A. oregonensis), winged floater 
(A. nuttalliana), western ridged mussel (Gonidea angulata), and western pearlshell mussel (Margaritafera falcata) (Frest and Johannes 1995). The California floater is listed as a federal species of concern in the United States and as a candidate species in Washington State; in addition, it is thought to be imperiled or critically imperiled throughout the Pacific Northwest (NatureServe 2009). Surveys in the lower Snake River in 1992 during a reservoir drawdown test revealed live adults of the California and western floaters and the western ridged mussel. These three mollusks now appear to be extirpated from the Lower Granite Dam Reservoir (Frest and Johannes 1992). The Oregon floater is known to occur in the Willamette, Columbia, Snake, and John Day rivers. NatureServe Explorer currently designates the Oregon floater as vulnerable in Washington and Oregon (NatureServe 2009).

The status of the western pearlshell mussel is largely unknown throughout the Pacific Northwest, although surveys of western Oregon and Washington have found abundant populations in several Oregon and Washington streams (Rensel 1992) and in the John Day River in central Oregon (Brim Box et al. 2004, 2006). Recent surveys have documented a relatively healthy population of western pearlshell mussel in the Willamette River and tributaries of the Umpqua River in western Oregon (Jason Dunham, U.S. Geological Survey, personal communication, July 2009). Archeological evidence with radiocarbon dates from 2,860 \pm 40 years before present (BP) to $140 \pm 40$ years BP supports the premise that the western pearlshell mussel persisted on the Hanford Reach (Marceau and Sharpe 2002). The western pearlshell mussel may be one of the longest-living freshwater invertebrates; the oldest known specimens are aged at greater than 90 years (Toy 1998), 100 years (Vannote and Minshall 1982), and more than 100 years old. ${ }^{1}$ Newell (2003) reported finding a few shells of the western pearlshell mussel downstream of the Hanford Site, but no mussels were described along the Hanford Reach. More recently (fall 2010), a small-scale survey was conducted along the shoreline of White Bluffs Slough. No pearlshell mussels were found, but several shells of the western floater were found near the silted-in regions and exposed cobble (Ted Poston, PNNL, personal communication, October 2010). The presence of dams and associated reservoirs that reduce water velocities and increase sedimentation is hypothesized to have contributed to the decline of the western pearlshell mussel and other mollusks. ${ }^{2}$ Mussels downstream from dams can be affected by scouring, unstable substrates, and fluctuating water elevations associated with dam operations.

\subsection{Study Objectives}

The objectives of this study were 1) to provide a more comprehensive characterization of the freshwater mussel species composition and distribution in the Hanford Reach, 2) to estimate mussel densities, and 3) to determine the age structure of mussel populations in the Hanford Reach. Although native mussels belonging to the Unionidae family have life spans of approximately 30 years, the western pearlshell mussel may live to more than 100 years of age. Thus, demographic information may provide some insight to current population of mussels inhabiting the shoreline regions of the Hanford Reach.

\footnotetext{
${ }^{1}$ Stock AL. 1996. Habitat and Population Characteristics of the Freshwater Mussel Margaritifera falcata in Nason Creek, Washington. Unpublished master's thesis, The Evergreen State College, Olympia, Washington.

${ }^{2}$ Anderson LP. 2002. Population Genetics and Conservation of the Freshwater Mussel Margaritifera falcata from the Northwestern United States. Unpublished master's thesis, University of Montana, Missoula.
} 


\subsection{Report Organization}

The site of this study - the Hanford Reach of the Columbia River - is described in Section 2. Section 3 documents the techniques employed by the research team to survey mussel species composition, density, and demographics as well as for riverbed characterization. Methods for data analysis and river environment classification also are covered in Section 3. Research results are provided in Section 4, followed by a discussion in Section 5. Sources cited in the text are listed in Section 6. An Appendix provides a detailed list of mussel species found during the 2004 survey. 


\subsection{Study Site}

The study was conducted within the Hanford Reach of the Columbia River, a 90-km river segment designated as a national monument in 2000 (Figure 2.1). The Hanford Reach is the last unimpounded stretch of the river and provides abundant suitable spawning habitats for fall Chinook salmon (Oncorhynchus tshawytscha) (Dauble and Watson 1997).

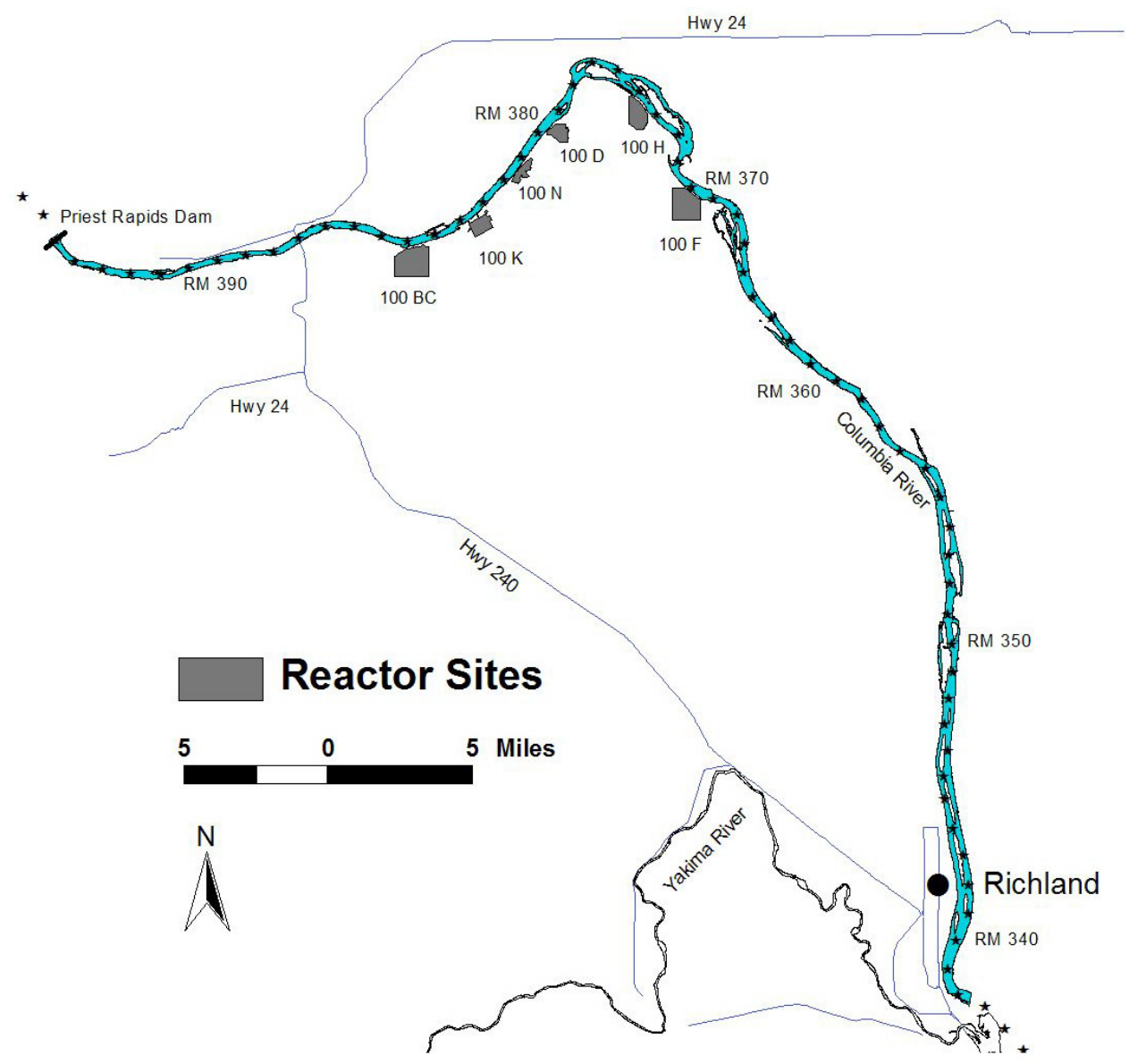

Figure 2.1. The Hanford Reach of the Columbia River in south-central Washington State.

The reach is composed of a series of pools and riffles and is braided with 20 relatively stable islands. The width of the Hanford Reach varies from about $240 \mathrm{~m}$ to 1,200 m. Mid-stream water depths can range from less than $4 \mathrm{~m}$ to more than $20 \mathrm{~m}$. The substrate conditions vary from fine sands and silt to large boulders and bedrock in certain areas. Rooted macrophytes are present in the sections with more embedded substrate and slower water velocity. Monthly mean discharge recorded at Priest Rapids Dam typically peaks between April and June during spring runoff from snowmelt and is lowest from September through October (DART 2009).

Water surface elevation along the Hanford Reach can vary daily, seasonally, and annually, depending on discharge rates and natural attenuation of the discharges governed by Priest Rapids Dam at RM 397 about $9 \mathrm{~km}$ upstream of the westernmost boundary of the Hanford Site. River elevation can fluctuate 2 to 
$3 \mathrm{~m}$ in areas near Priest Rapids Dam. The Federal Energy Regulatory Commission has established a minimum flow rate of $1,086 \mathrm{~m}^{3} / \mathrm{s}$ through the Hanford Reach. Based on 68 years of data from Priest Rapids Dam, the average annual rate of flow in the Hanford Reach was approximately $3,400 \mathrm{~m}^{3} / \mathrm{s}$ (McGavock et al. 1987). Between 1994 and 2002, the average flow rate determined from hourly discharge measurements from Priest Rapids Dam was $3,466 \mathrm{~m}^{3} / \mathrm{s}$ and ranged from $1,124 \mathrm{~m}^{3} / \mathrm{s}$ to $8,566 \mathrm{~m}^{3} / \mathrm{s}$. Impounded waters caused by McNary Dam, the downstream hydroelectric facility, begin to interface with the free-flowing waters of the Hanford Reach approximately $5 \mathrm{~km}$ upstream of Richland, Washington (see Figure 2.1). 


\subsection{Methods}

\subsection{Survey Techniques for Species Composition, Density, and Demographics}

Snorkel-based surveys were employed to locate, identify, and measure live native mussels (Strayer and Smith 2003). Snorkelers surveyed the riverbed for mussels at a distance not greater than $1 \mathrm{~m}$ from the river bottom to minimize the chance of missing mussels, particularly those individuals deeply embedded in the river substrate. To account for this variable, all surveys were conducted at depths of 1 to $2 \mathrm{~m}$ below the low-water mark, a section along the shoreline that was visually identified by the persistent colonies of periphyton growing on rock surfaces. This persistently inundated section corresponds to a river flow of approximately $2,265 \mathrm{~m}^{3} / \mathrm{s}$ (Turner 2004), which represents the minimum flow level typically allowed by Priest Rapids Dam. Organisms living below this depth are assumed to be inundated yearround.

Surveys were conducted along 2-m-wide transects that extended from 25 to $435 \mathrm{~m}$ into the channel, depending on the depth of the water, extent of the substrate, and presence of macrophytes. A transect survey was ended if one or more characteristics of substrate size, embeddedness, or macrophytic abundance changed.

Species were identified based upon morphological characteristics of the shell and the taxa recognized by Turgeon et al. (1998). In addition, the species were subsequently verified by consultation with Deixis Consultants (Seattle, Washington) from examination of several shells of the mussels retained from the surveys. Some of the individuals belonging to the Anodonta genus were difficult to identify to the species level currently prescribed for Anodonta. As such, measurements of shell length (dorsal to ventral), width (anterior to posterior), and height (cusp to cusp) were taken on most specimens encountered along the snorkel transects. Initially, Anodonta spp. encountered along the snorkel transects were distinguished as either California floater or Oregon/western floater. Later, the distinction between Oregon floater and western floater was recorded on 13 transects and 93 individuals after field crews became more familiar with the specimens encountered.

Three live specimens of each species belonging to the Anodonta genus were retained as voucher specimens. Shell and soft tissues from these three specimens were preserved in $99 \%$ ethanol and archived by Deixis Consultants.

\subsection{Riverbed Characterization}

The snorkel-based survey transects for mussels along the Columbia River were classified according to the variables of dominant and subdominant substrate (Platts et al. 1983), substrate embeddedness (degree to which interstitial spaces between cobble are filled with sand or silt), and the relative abundance of macrophytes (rooted aquatic vegetation). These characteristics were determined at the beginning of each transect survey. The primary substrate class was defined as the most abundant substrate (dominant) in the area and was determined visually by the field team members. The secondary substrate was defined as the next most abundant substrate present (subdominant). Representative rocks were then selected for both dominant and subdominant substrates, and the medial axis was measured (in centimeters) and recorded 
consistent with the parameters listed in Table 3.1. The degree of substrate embeddedness (matrix substrate) was classified along each transect as one of four categories (Table 3.2). The presence and relative abundance of aquatic vegetation (macrophytes) as seen from above the water surface were also noted along each transect. The relative abundance of macrophytes was classified as follows: 1) no vegetation present, 2) sparse vegetation and substrate completely evident, 3) vegetation common and substrate partially obscured, and 4) dense vegetation and substrate nearly or completely obscured (Figure 3.1).

Table 3.1. Dominant and subdominant substrate classifications used during the 2004 native mussel surveys (from Platts et al. 1993).

\begin{tabular}{llc}
\hline Category & Substrate Classification & $\begin{array}{c}\text { Apparent Range } \\
\text { Particle Diameter Size } \\
(\mathrm{cm})\end{array}$ \\
\hline 1 & $\begin{array}{l}\text { Fines, sand, silt, and } \\
\text { mud }\end{array}$ & $<0.6$ \\
\hline 2 & $\begin{array}{l}\text { Gravel-medium } \\
\text { cobble }\end{array}$ & $0.6-15.2$ \\
\hline 3 & Large cobble & $15.2-30.5$ \\
4 & Boulder/bedrock & $>30.5$ \\
\hline
\end{tabular}

Table 3.2. Classifications of substrate embeddedness (\% fines) measured during the 2004 native mussel surveys.

\begin{tabular}{lcl}
\hline Category & $\begin{array}{c}\text { Substrate Embeddedness } \\
\text { (\% fines) }\end{array}$ & \multicolumn{1}{c}{ Description } \\
\hline 1 & $0-25$ & $\begin{array}{l}\text { Openings (distance) between dominant size particles are one- } \\
\text { third to one-half the size of the particles, with few fines between } \\
\text { and clearly discernable edges. }\end{array}$ \\
\hline 2 & $26-50$ & $\begin{array}{l}\text { Openings are apparent but less than one-fourth the size of the } \\
\text { particles. Edges are discernable but up to one-half obscured. } \\
\text { Openings are completely filled, but half of the edges are still } \\
\text { discernable. }\end{array}$ \\
\hline 4 & $71-75$ & $\begin{array}{l}\text { All openings are obscured. Only one or two edges are } \\
\text { discernable, and size cannot be determined without removal. }\end{array}$ \\
\hline
\end{tabular}

\subsection{Data Analysis}

Mussel densities were determined for each transect based on the area surveyed and the number of individual specimens observed per $100 \mathrm{~m}^{2}$. The average, median, and maximum of mussel densities were calculated for the physical habitats in which they were found. Additional data were summarized related to the demographics of selected species and densities in general river classifications based on river geomorphology. 

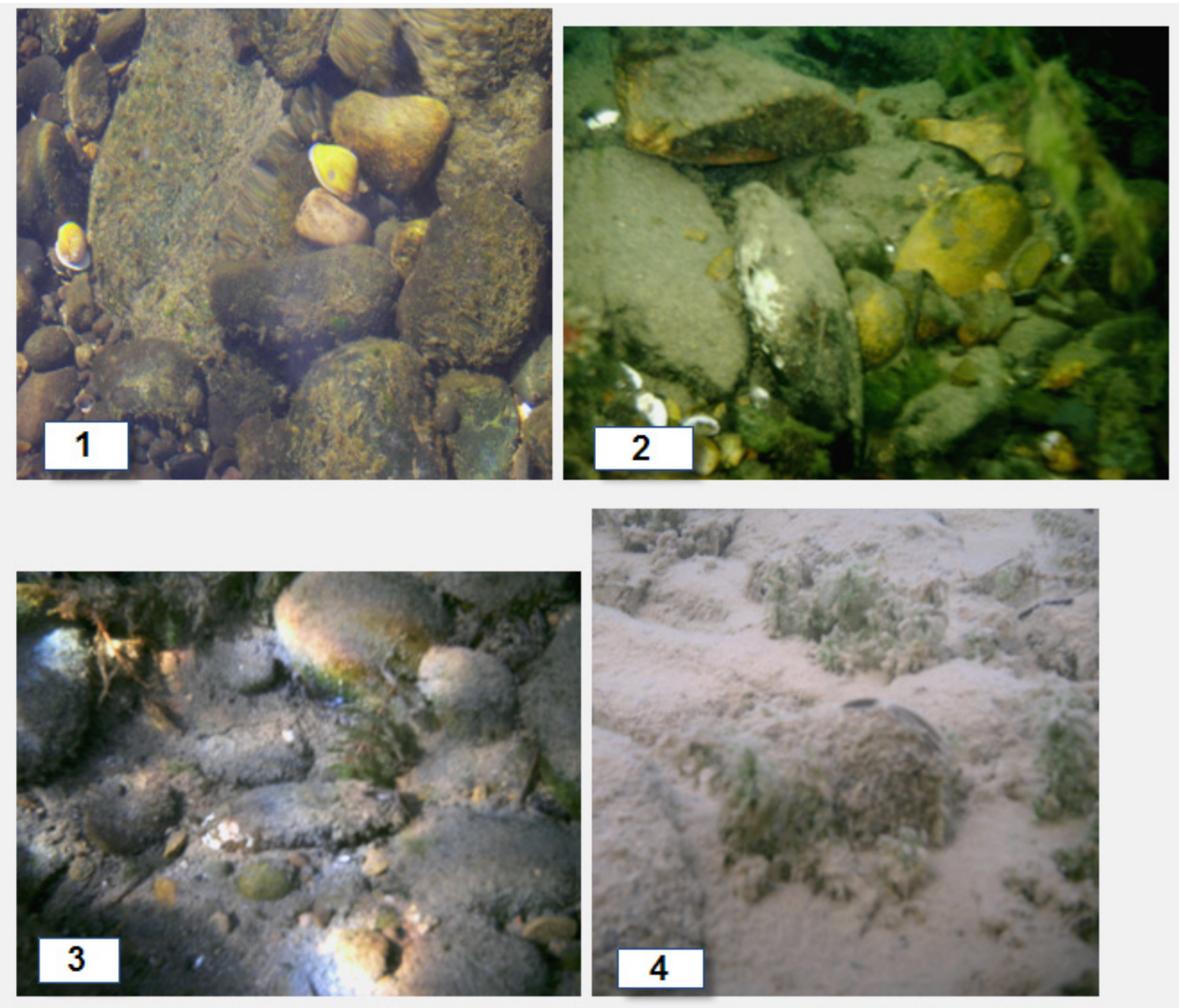

Figure 3.1. The four embeddedness categories as described in Table 3.2.

\subsection{Classification of the River Environment}

To determine the existence of a relationship between the geomorphology of the river and the associated assemblages of organisms found, we compared the distribution of mussels to three general river classifications. The physical variables measured on each transect (see Section 3.2) are not necessarily independent and may be factors that collectively can be represented using the geological and hydrological characteristics of the river.

The aquatic environment was partitioned into segments of the river based on the shape of the river channel. Each segment was then classified by two primary criteria-planform and geomorphology. The planform and geomorphology information (based on river segments 1 to 5 channel widths in length) were used to separate or stratify the Hanford Reach into channel classifications that were systematically 
measured between Richland and the Vernita Bridge based on aerial imagery (Dauble et al. 2003;

Table 3.3). The channel classifications were defined as follows:

- riverine channels - flowing water within a single channel

- island-adjacent channels - flowing water contained within a braided channel

- slough or backwater channels - areas known to contain very low-velocity flow outside the main river channel.

Table 3.3. General river classes between Richland and the Vernita Bridge and the number of transects selected and surveyed for native mussels during 2004.

\begin{tabular}{lccc}
\hline & \multicolumn{2}{c}{$\begin{array}{c}\text { Spatial Extent of River } \\
\text { Classes between } \\
\text { 300 Area to near } \\
\text { Vernita Bridge }\end{array}$} & \\
\cline { 2 - 3 } River Classification Types & $\begin{array}{c}\text { No. of } \\
\text { Segments }\end{array}$ & $\begin{array}{c}\text { Percentage } \\
\text { of Total }\end{array}$ & $\begin{array}{c}\text { No. of } \\
\text { Transects }\end{array}$ \\
\cline { 1 - 3 } Riverine channels & 87 & 58.9 & 19 \\
\cline { 1 - 2 } Island-adjacent channels & 58 & 39.5 & 26 \\
Slough or backwater channels & 2 & 1.4 & 7 \\
\hline Totals & 147 & 100 & 52 \\
\hline
\end{tabular}

\subsection{Sampling Design}

A number of transect points were selected randomly using an ArcView geographic information system (GIS) representation of the Hanford Reach in 3-m- $\times 3-\mathrm{m}$-pixel resolution. In addition, a number of transects were selected subjectively to 1) obtain samples from river classes that were not selected randomly, 2) better describe the mussel species compositions in areas where mussel shells had been noted during other field activities, 3) increase precision of the mussel density estimates in areas where they were frequently encountered, and 4) survey for mussels in areas near Hanford Site facilities (Figure 3.2). All survey sites except for one were located along the Benton County shoreline (south shoreline). The exception was the survey site where shells of the western pearlshell mussel had been found during August 2003 (Brett Tiller, Environmental Assessment Services, personal communication, 2003). 


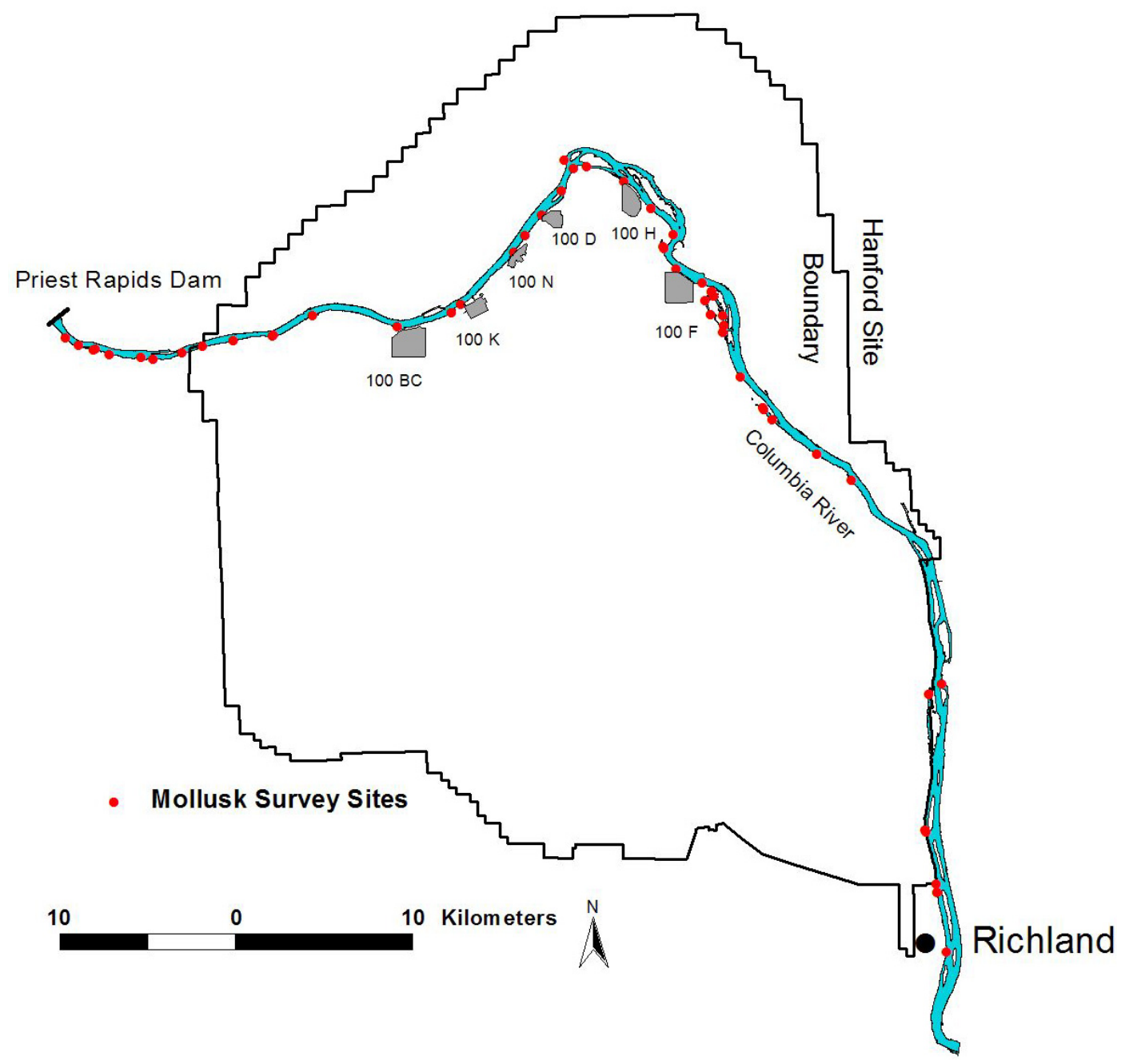

Figure 3.2. Sites surveyed for native mussels along the Benton County shoreline of the Hanford Reach in 2004. 


\subsection{Results}

\subsection{Species Composition and Relative Abundance Estimates}

Three species belonging to the Anodonta genus were observed during the 2004 sampling efforts; these included the western, California, and Oregon floater (Figure 4.1). Shells of the western pearlshell mussel were found at only 2 of the 52 sampling sites visited during 2004. Three shells were found near RM 350 along the Franklin County shoreline, and a single shell was found near the 100-D Area at RM 377. No live specimens of the western pearlshell mussel were found, but inspection of the shells (purple coloration of exterior shell and integrity of ligament) indicated they likely had died within the past 10 years. Four individual mussels that appeared morphologically unique were encountered at two sites on the lower portion of the Hanford Reach. Because these individuals could not be classified to species based on the ratio of shell length to height less than 2 but greater than 1.5, they were omitted from the composition analysis described in this section. A shell length-to-height ratio of greater than 1.5 designated the California floater, and a shell with a ratio of close to or exceeding 2 was classified as a western or Oregon floater. The average ratios of shell length to depth for each species measured are shown in Figure 4.2. Other factors used to key the species of Anodonta included umbo (beak) position in relation to hinge line, shell color, or wing characteristics. Three specimens of each taxa belonging to the Anodonta genus were collected, and samples of the adductor muscle were preserved in $99 \%$ ethanol and archived. No further identification was done with the preserved samples.

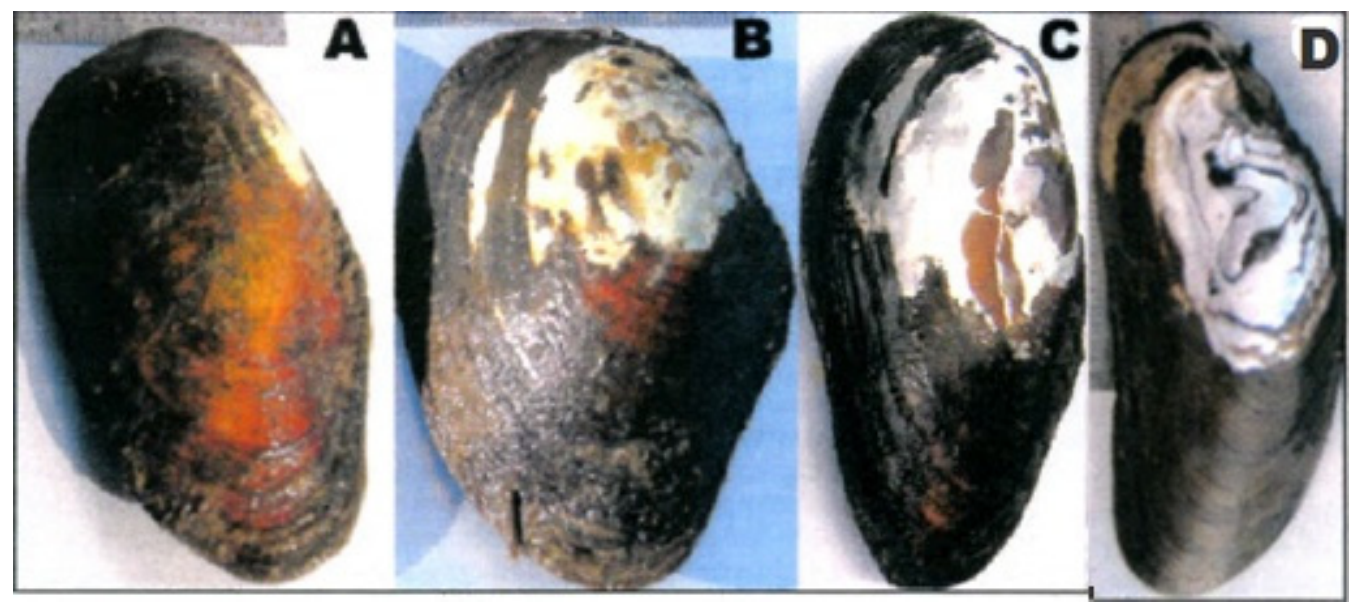

Figure 4.1. Mussel species observed along the Hanford Reach during 2004. (A) western floater, (B) California floater, (C) Oregon floater, and (D) western pearlshell mussel.

The most common and widespread mussel found was the western floater. The next most abundant mussel was the Oregon floater. California floaters were the least abundant, although they were more abundant than the Oregon floater in the sloughs and backwater channels. Figure 4.3 illustrates this pattern by showing the relative abundance based on density of total area searched of all three species on the 13 transects of riverbed sampled and indentified to species. 


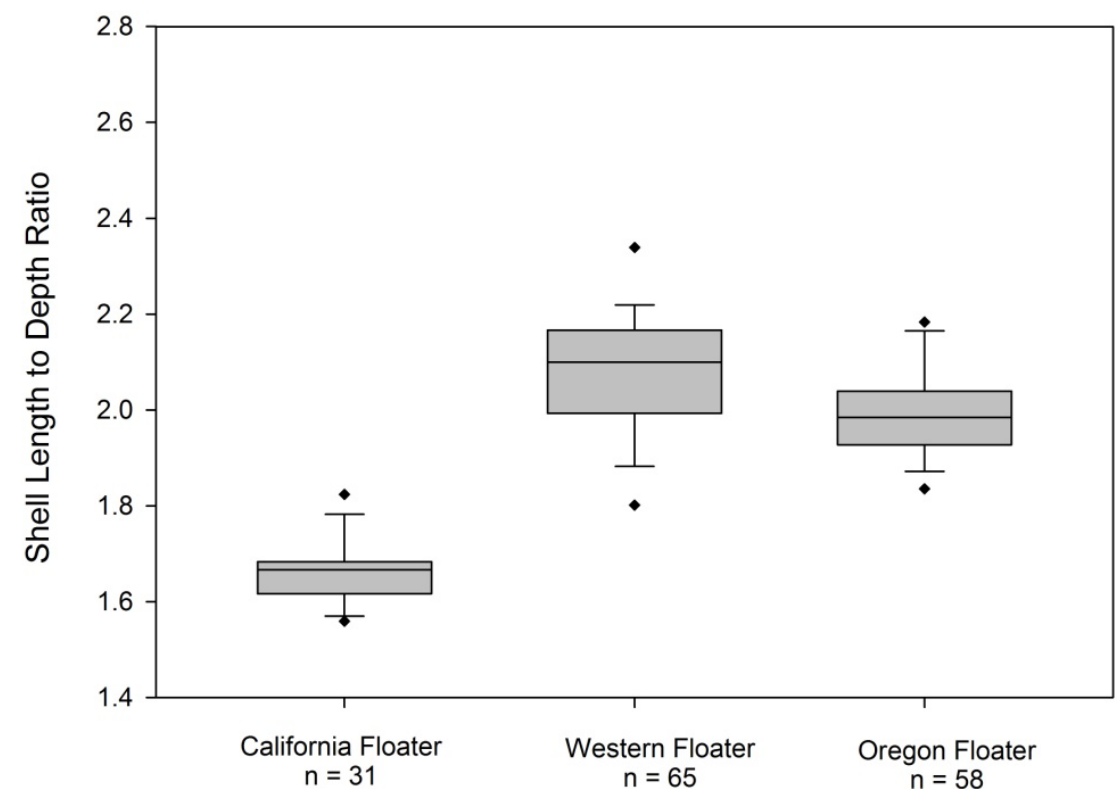

Figure 4.2. Average shell length-to-depth ratios of Anodonta species measured along the Hanford Reach in 2004.

\subsection{Mussel Density}

A total of 200 live individual specimens were observed along 52 snorkel transects that covered $28,432 \mathrm{~m}^{2}$ of riverbed (see Figure 4.3), for an overall density of 0.7 mussels $/ 100 \mathrm{~m}^{2}$ and a range from 0.0 to 8.4 mussels $/ 100 \mathrm{~m}^{2}$ for each transect. Mussel densities varied across river classification and substrate embeddedness, dominant substrate types, and the relative abundance of macrophytic vegetation (Figures 4.4 through 4.6). These variables are not completely independent, but some patterns associated with each were apparent.

Figure 4.4 shows the mussel density in relation to substrate embeddedness from all 52 transects. The California floater was found principally in areas where the substrate was fully embedded with sand/silt materials (embeddedness category 4). The highest density of the western and Oregon floater combined ( 9.3 individuals $/ 100 \mathrm{~m}^{2}$ ) also was found in fully embedded substrates. However, Figure 4.4 shows that these two species were frequently found also in areas where substrate was partially embedded (embeddedness categories 2 and 3).

Overall, mussel densities were greatest in the sand/silt substrate (category 1) and pebble substrate (category 2) compared to the cobble substrate (category 3 ) and boulder substrate (category 4)

(Figure 4.5). The California floater was found only in areas with pebble substrates (category 2), whereas the Oregon floater and western floater were frequently encountered also in areas where the dominant substrates were sand/silt (category 1). The western and Oregon floater densities were combined because of their occurrences in similar habitats. 


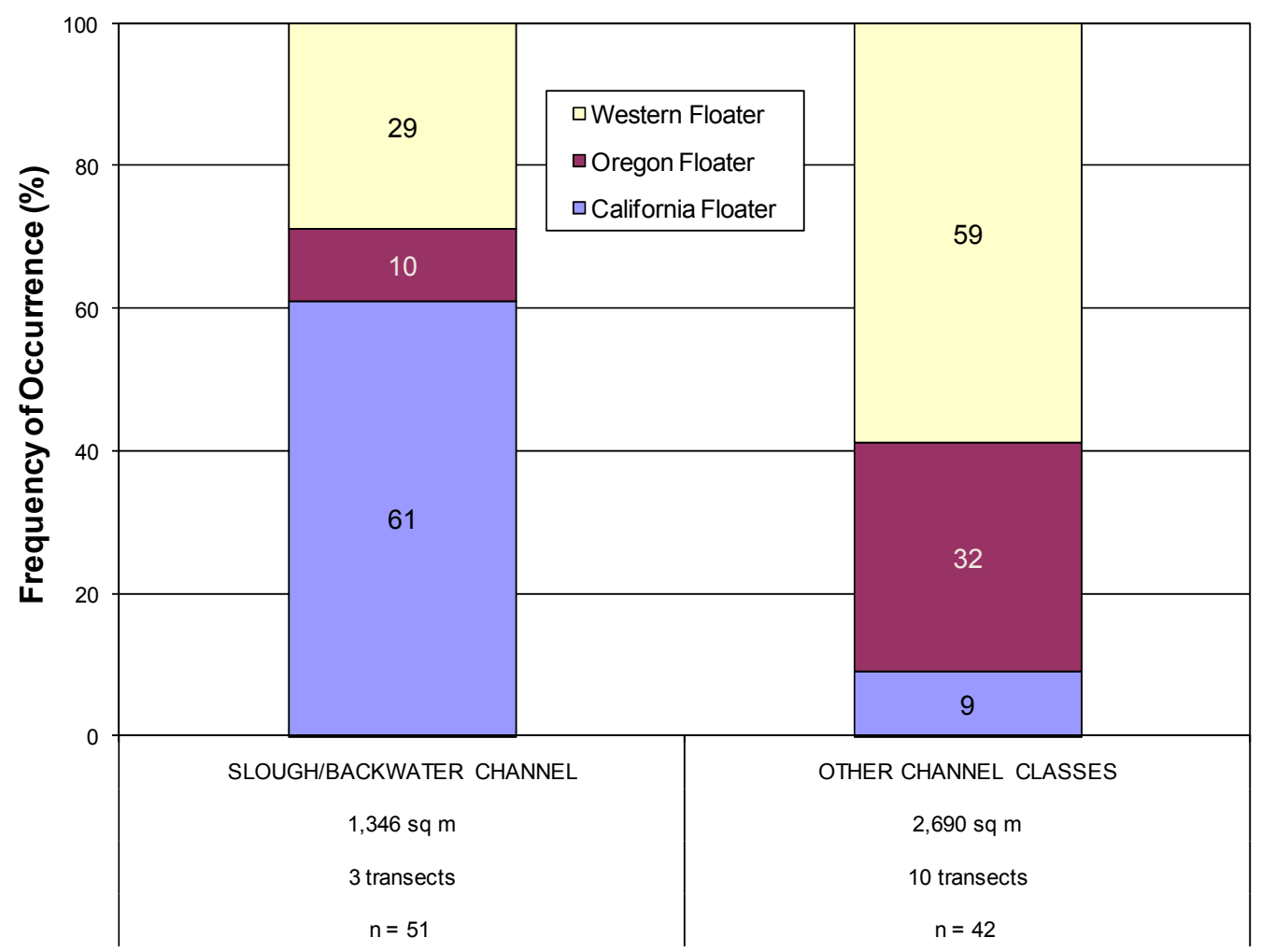

Figure 4.3. Relative abundance of native mussels found along the Hanford Reach during 2004.

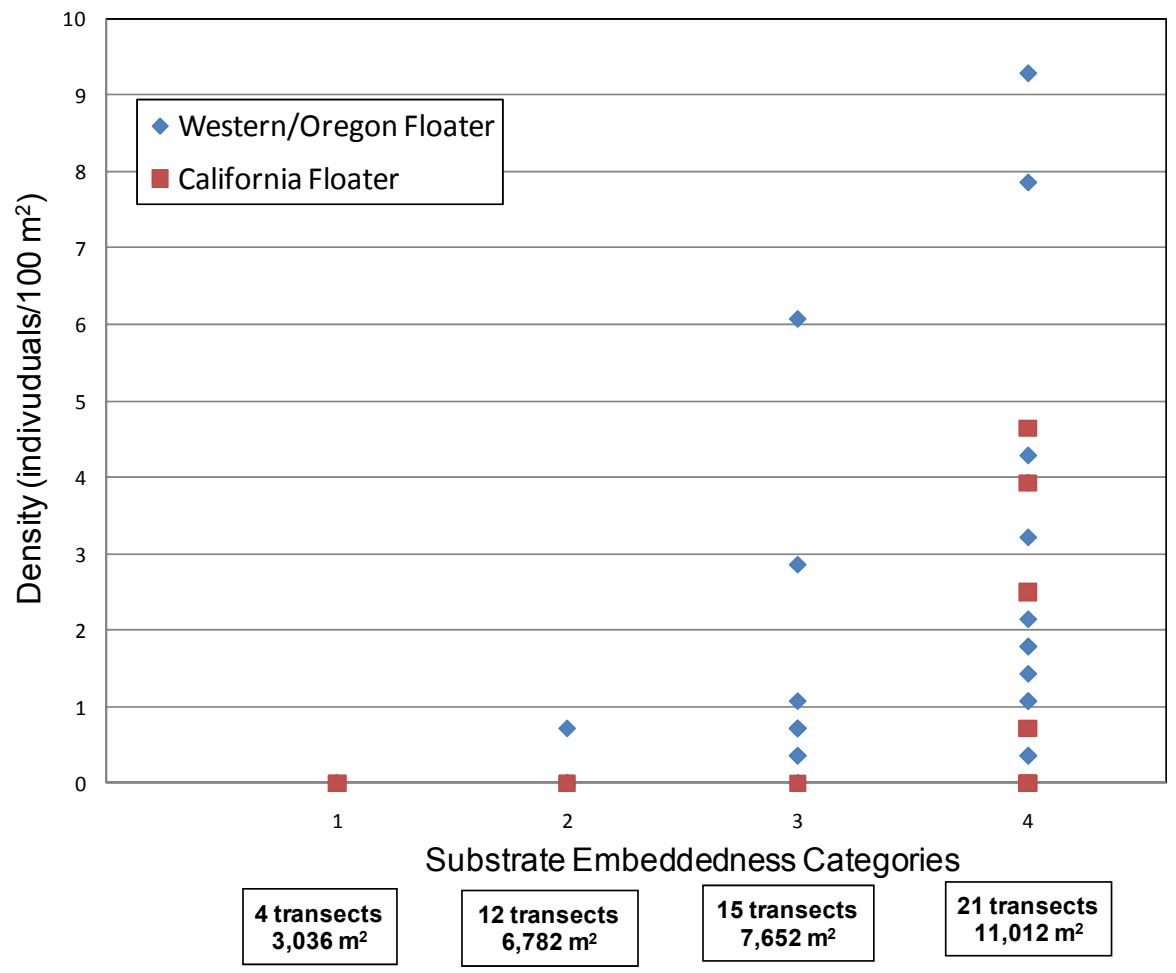

Figure 4.4. Densities of native mussels (individuals $/ 100 \mathrm{~m}^{2}$ ) relative to substrate embeddedness for all 52 transects. 


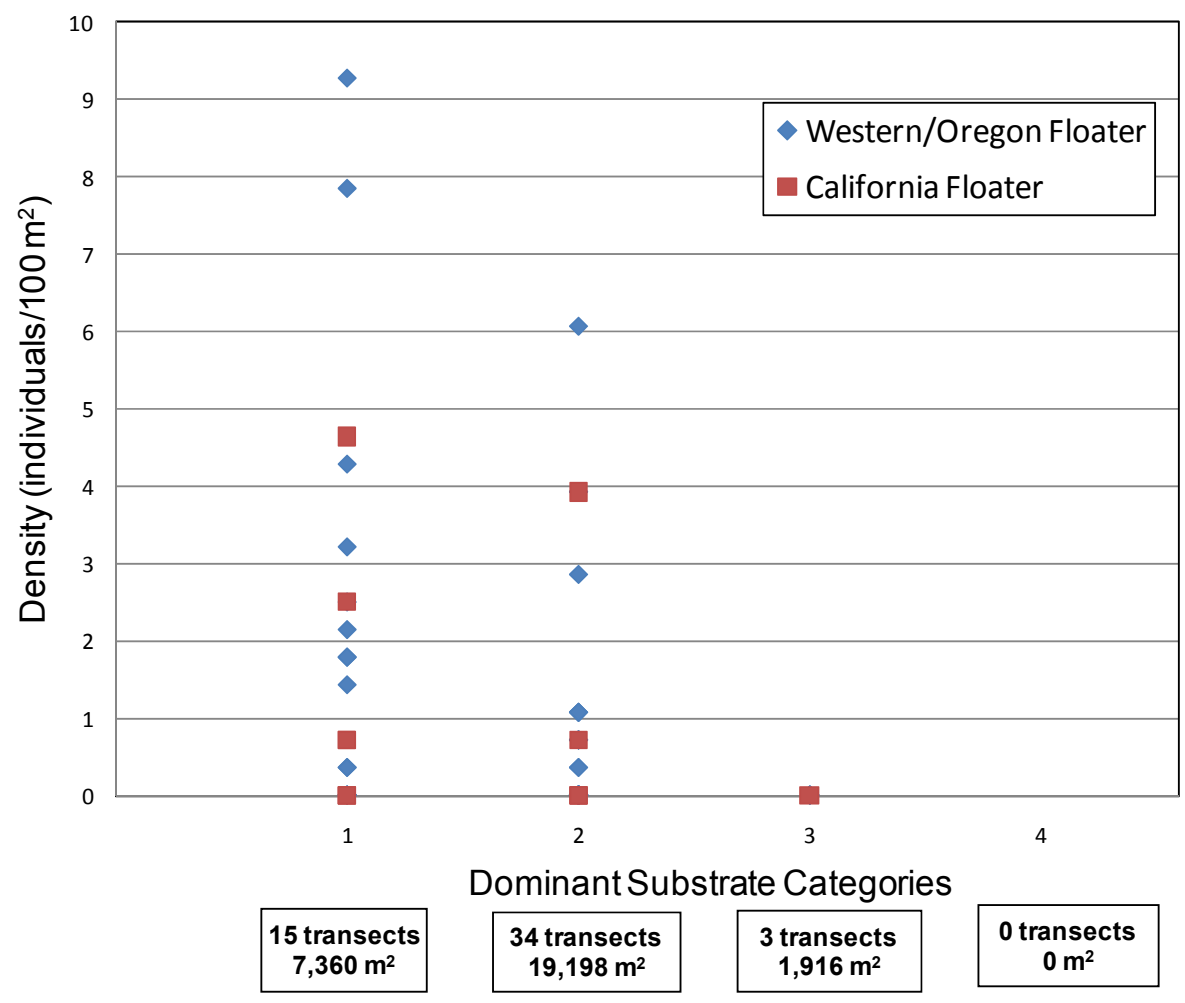

Figure 4.5. Densities of native mussels (individuals $/ 100 \mathrm{~m}^{2}$ ) relative to dominant substrate for all 52 transects.

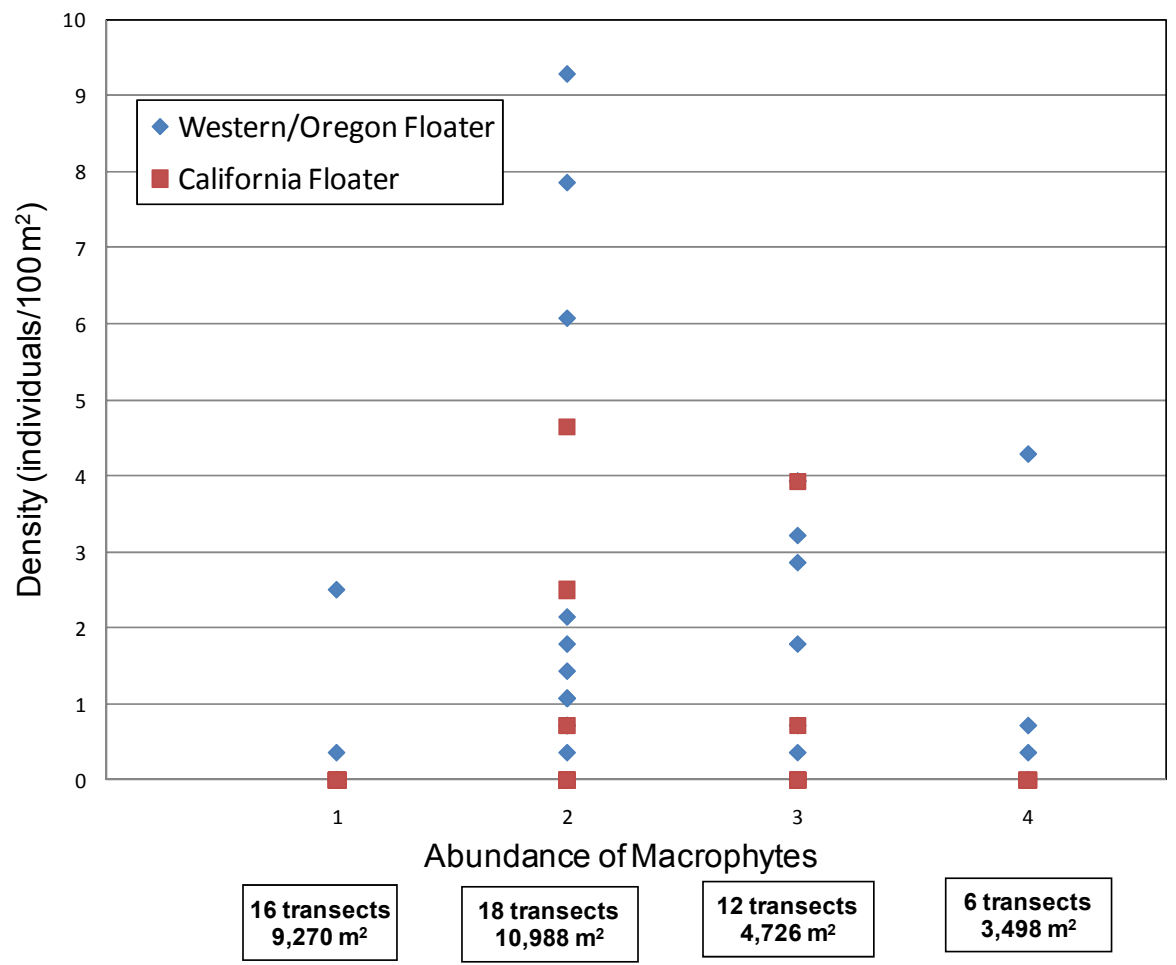

Figure 4.6. Densities of native mussels (individuals $/ 100 \mathrm{~m}^{2}$ ) based upon relative abundance of macrophytic vegetation for all 52 transects. 
Mussel densities appeared to be related also to the amount of aquatic vegetation (macrophytes) recorded along transects (Figure 4.6). Mussels were found on only 2 of 16 transects in areas devoid of macrophytic vegetation (relative abundance category 1 ), and the species found were either western or Oregon floater. The highest densities of three of the four mussel species found were recorded in areas where macrophytic vegetation was scattered (category 2) or common (category 3 ) and substrates were still readily visible. No mussels were detected on 3 of 6 transects conducted in very abundant macrophytic vegetation (category 4), and the mussel densities found on the other 3 transects averaged approximately 1 mussel $/ 100 \mathrm{~m}^{2}$ (for western floater or Oregon floater).

Little variation in Anodonta spp. mussel densities was observed across the three river classes that were described to collectively account for hydrological and geomorphic factors that may affect the distribution and densities of mussels. Riverine and slough/backwater channels contained the highest densities (nearly 3.5 specimens $/ 100 \mathrm{~m}^{2}$ ), and the island-adjacent regions contained slightly less at 2.5 mussels $/ 100 \mathrm{~m}^{2}$ (Figure 4.7).

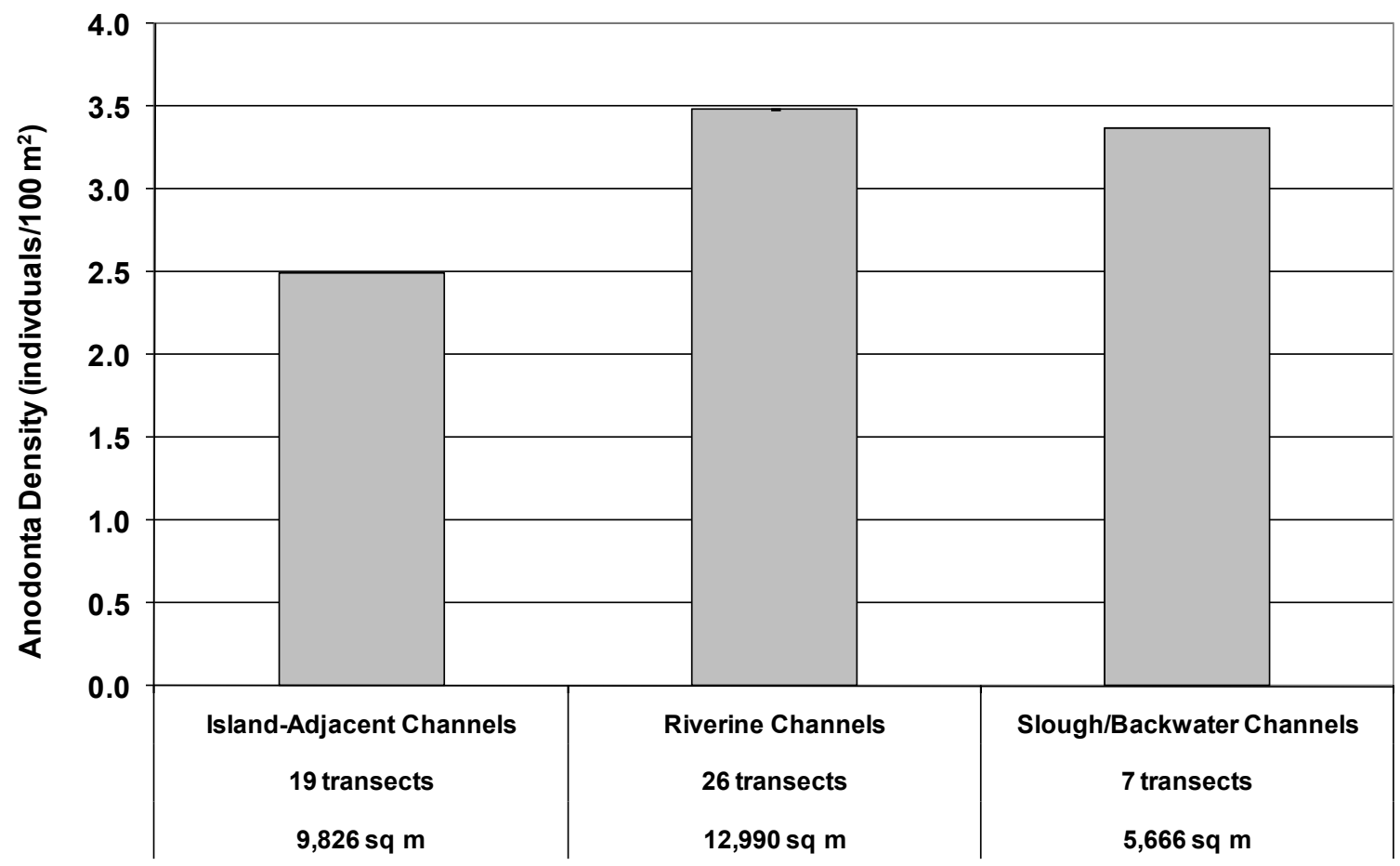

River Classification

Figure 4.7. Mean density of Anodonta spp. (individuals $/ 100 \mathrm{~m}^{2}$ ) relative to river channel classification.

\subsection{Spatial Distributions}

Mussel density results were sorted into two general categories of relative abundance - medium/low $\left(<2.5 / 100 \mathrm{~m}^{2}\right)$ and high $\left(>2.5 / 100 \mathrm{~m}^{2}\right)$. These were evaluated with respect to a GIS-based depiction of river classes along the entire Hanford Reach (Figure 4.8). Relatively high densities of all three Anodonta species were expected in the slough/backwater river class; this class constitutes approximately $1.5 \%$ of the river environment along the Hanford Reach (see Table 3.3). The other two river classes found to contain at least some mussels had medium to low mussel densities. Areas other than slough/backwater 
constitute approximately $60 \%$ of the river environment along the Hanford Reach (see Table 3.3 ). Medium to low mussel densities are expected to occur throughout much of the downstream portion of the Hanford Reach. In contrast, native mussels are not likely to occur in about $35 \%$ of the Hanford Reach, and relatively very few areas suitable for native mussels were estimated to be present in the upper sections of the Hanford Reach (see sections in Figure 4.8 between the upriver boundary of the Hanford Site downriver to approximately the 100-D Area). The survey results also indicated that the California floater was found in only a few areas and was associated largely with the slough/backwater river class (see Figure 4.3).

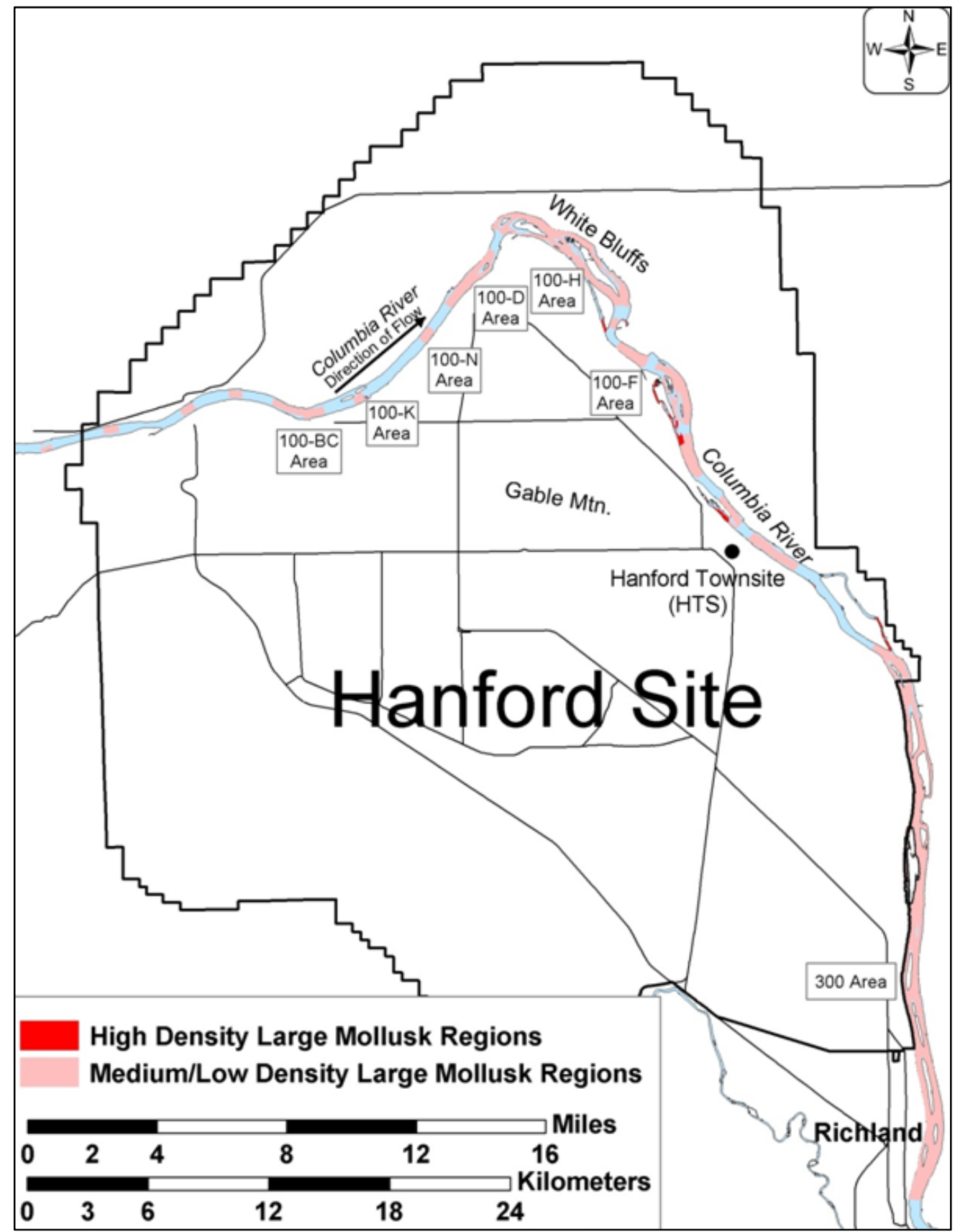

Figure 4.8. Estimated relative abundance and distribution of native mussels along the Hanford Reach, 2004. 


\subsection{Size Distributions}

Shell lengths are used to indicate the age structure of mussel populations. However, relative small size classes ( $\sim 30 \mathrm{~mm}$ or less) were not expected to be found using the techniques employed during this study due to small size of the shell, making observation more difficult. Thus, the age classifications are biased toward the larger and older age classes of the shells that were measured.

Anodonta are relatively short-lived and fast-growing mussels that reach sexual maturity in 4 to 5 years and have a life span of approximately 15 years. Figure 4.9 shows the size distribution of 198 mussels that were measured and identified to the species-level. These results represent the 93 individuals collected on 13 transects and an additional 105 individuals located in the slough/backwater channels to increase the sample size. All three species of Anodonta exhibited similar size-class structures. The probability of a normal distribution for the California floater was 0.93 , western floater 0.97 , and Oregon floater 0.96 . The largest shell sizes were found to occur for the western floater; ranging from $84 \mathrm{~mm}$ to $143 \mathrm{~mm}$, these were slightly larger than those of the other two species. The size ranges for the three species were as follows:

- California floater, $62-132 \mathrm{~mm}$

- Oregon floater, 47-137 mm

- western floater, 84-143 mm.

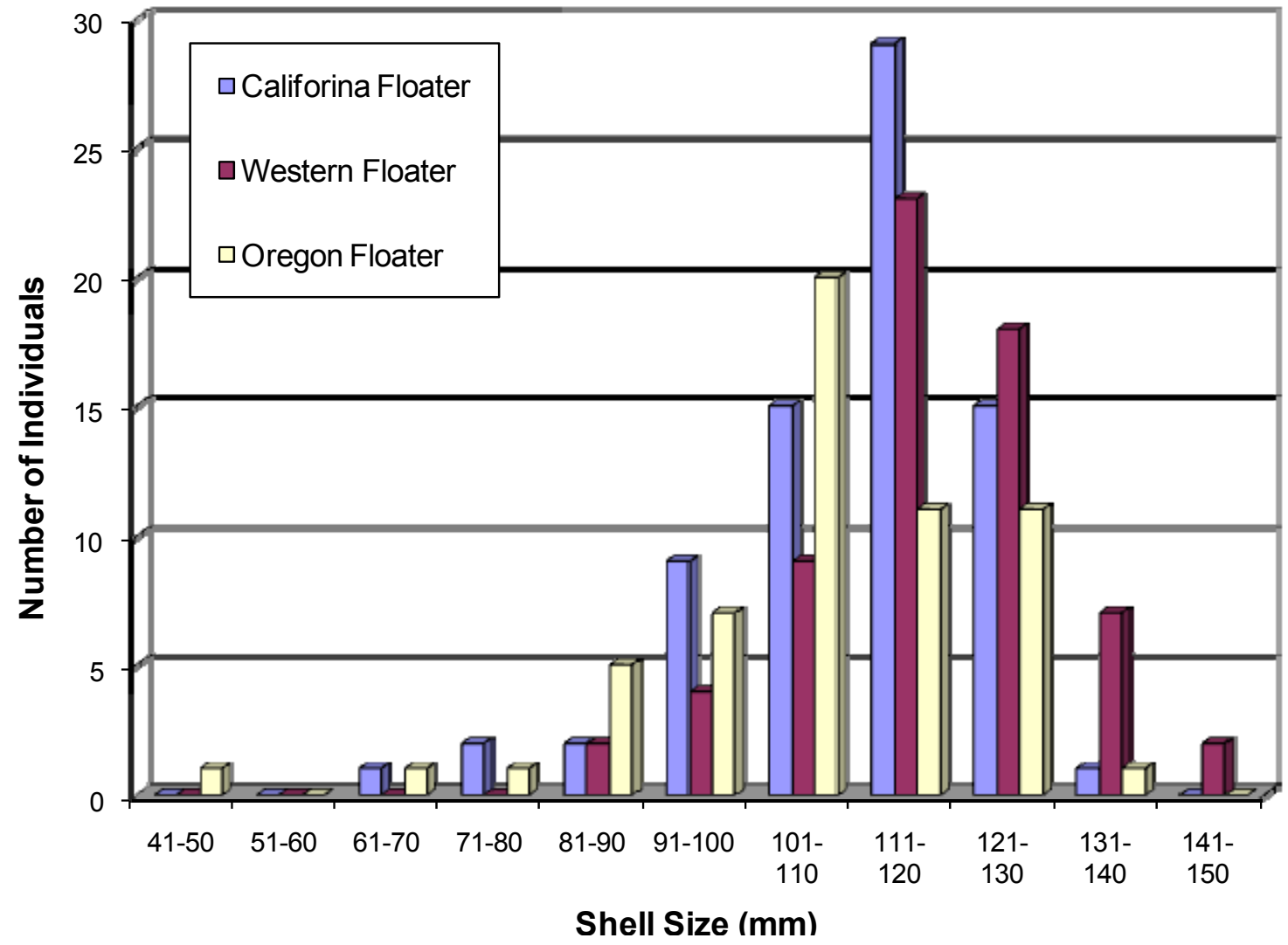

Figure 4.9. Size distribution of shell length of Anodonta species collected and measured along the Hanford Reach during 2004. 


\subsection{Discussion}

This study was intended to provide an initial assessment of the species composition, densities, and distribution of native mussels along the Hanford Reach of the Columbia River. The results indicated that three species belonging to the Anodonta genus reside in a number of shallow areas along the Hanford Reach. The California floater was found in four areas and generally in those areas with high substrate embeddedness and very low river water velocities. The western floater and Oregon floater were frequently encountered in a number of locations where the riverbed was at least partially embedded. The surveys showed that the western pearlshell mussel was almost completely absent during 2004. Shells of some adults were found on 2 of the 52 transects surveyed during 2004 and indicate a few small populations of the western pearlshell mussel may still exist at water depths greater than these surveyed during 2004.

The conservation status of the western pearlshell mussel was ranked as secure by NatureServe in 2009, although its status is critically imperiled in Washington State (NatureServe 2009). Archeological evidence along the Hanford Reach indicates the western pearlshell mussel persisted there and was used extensively by Native Americans for thousands of years $(\sim 3,000$ to 140 years BP) (Marceau and Sharpe 2002). Why this species appears to be almost extirpated along the Hanford Reach today remains uncertain. A wide variety of factors such as siltation, nutrient enhancement, unstable substrate, river impoundments, and fluctuating flows may contribute to the decrease of this species in large river systems such as the mid- and lower Columbia River. Several populations of the western pearlshell mussel are found in streams of western Washington State, including Bear and Cottage Lake creeks in King County, where densities of up to 150 mussels per/ $0.5 \mathrm{~m}^{2}$ have been documented (Rensel 1992). Recent surveys in the Clearwater River in western Washington found western pearlshell to be flourishing with estimated populations of 15,000 individuals/700 $\mathrm{m}^{2}$ in a $69-\mathrm{m}$ section of the river (Helmstetler and Cowles 2008). Western pearlshell mussels found in western Washington streams inhabited areas with large stable heterogeneous cobble- to boulder-size rocks with an intermix of fine substrates and water velocities of $0.2-0.3 \mathrm{~m} / \mathrm{s}$ (Frest and Johannes 1995; Toy 1998; Turgeon 1998). These conditions appeared to exist in several areas of the Hanford Reach during 2004, but only a few shells from individuals were found along 2 of the 52 transects sampled during 2004. A peculiar coincidence was noted during 2004 when the smallest living mussel (a 47-mm-long Oregon floater) found during these surveys was encountered at the only site where several western pearlshell mussel shells also were found.

The western ridged mussel (Gonidea angulata) was expected to be present based on previous observations throughout the rivers of eastern Washington (Frest and Johannes 1995). However, none were found along the Hanford Reach during the 2004 survey, nor were any shells of this species observed. The status of the western ridged mussel is currently thought to be imperiled throughout the Pacific Northwest (NatureServe 2009). This species typically is found in sand/silt-dominated areas and has been observed in the Columbia River, upstream of Priest Rapids Dam (Frest and Johannes 1995). It remains in portions of the Snake River system, Okanogan River in Washington, and Clearwater River, Hells Canyon, and middle Snake River in Idaho but appeared to be extirpated from many former locations (Frest and Johannes 1995).

The mussel densities observed during this study were variable; the highest densities occurred in areas where substrates include some sand/silt. Two species, the western and Oregon floater, were found in virtually all substrate types sampled (sand/silt, pebble, and cobble), provided there was some degree of 
embeddedness (matrixed substrate). The relative abundance of macrophytic vegetation also appeared to be related to the densities of mussels because the highest mussel densities were found when macrophytes were scattered (category 2). Mussel densities appeared to be lower where the macrophytes were very abundant (category 4). Reduced visibility may have affected these results; however, snorkeling observers compensated for this impairment by spending more time per meter to ensure the mussels present were accurately observed and consistently counted. The physical constraints of the river likely limit mussel distributions because much of the river environment along the Hanford Reach comprises relatively clean cobble with little fine-grain silt/sands embedded between the primary substrates. The Hanford Reach appears to have had no major changes in river planform and channel cross-sectional characteristics over the past century (Dauble and Geist 2000). Riverbed materials in the Hanford Reach are thought to be sufficiently coarse to resist movement by flows as high as the regulated 100-year frequency discharge (i.e., $12,500 \mathrm{~m}^{3} / \mathrm{s}$; Dauble and Geist 2000).

Mussel densities obtained from 52 transects consisting of $28,432 \mathrm{~m}^{2}$ of riverbed surveyed were used as a coarse index to illustrate the areas in which high and medium to low species composition and densities would be expected. The greatest mean densities of Anodonta spp. found during this study were only 3.5 individuals $/ 100 \mathrm{~m}^{2}$, and Toy (1998) suggested that if mussel density (the average density within a $0.08-\mathrm{km}$ radius) is less than $10 / \mathrm{m}^{2}$, reproductive success may be too low to sustain a population. The slough/backwater river class comprised approximately $1.5 \%$ of the Hanford Reach and contained relatively high densities and diversity of native mussels found during 2004. The western floater and the Oregon floater were found in river classes that represent about $65 \%$ of the river environment along the Hanford Reach. Conversely, relatively high densities of the California floater are expected in only 1.5\% of the river environment, and low densities may be expected to occur in about $45 \%$ of the river environments. The river classes containing mussels were consistently identified throughout most of the lower sections of the Hanford Reach compared to a more limited distribution in the upper sections. However, some of the river classes were not well represented in the datasets collected during 2004.

NatureServe Explorer provided a relatively comprehensive review and general status and distribution of the native freshwater mussel populations throughout the Pacific Northwest. Populations of the California floater, a federal species of concern and Washington State candidate species, are currently thought to be critically imperiled (substantial population declines are known, and extirpation of the species is an eminent concern) in Washington, Nevada, Utah, and Arizona (NatureServe 2009). This species was once thought to have been widespread in the Pacific drainage from British Columbia into Mexico. Frest and Johannes (1995) documented the range of California floater in the following areas: the middle Snake River in Idaho; the Fall and Pit rivers in Shasta County, California; the Okanogan River in Chelan County, Washington; and Roosevelt and Curlew lakes in Ferry County, Washington. No living specimens were found in the Willamette and lower Columbia rivers in searches by Frest and Johannes conducted from 1988 to 1990 . This species typically prefers sand/silt substrates, as was found in all three slough/backwater regions on the Benton County shoreline of the Hanford Reach (see mussel high-density areas shown in Figure 4.8). Element occurrences of freshwater mussels are defined as areas where one or more individuals of the species have been documented. Individual element occurrences are typically separated by a distance of more than 2 stream kilometers of unsuitable habitat, or a distance of more than 10 stream kilometers of apparently unoccupied though suitable habitat (NatureServe 2009). As such, the three high-density sections identified in Figure 4.8 appear to qualify as individual element occurrences (based on habitat distance variables) for the California floater. The 2004 study also found the California floater to be relatively abundant along the two transects located nearest to the city of Richland. The 
Oregon floater is currently listed as vulnerable in Washington and Oregon, and the western floater is listed as secure or not ranked in the Pacific Northwest.

Mussel shell lengths are used as an indication of the population age structure (Toy 1998). The life span of Anodonta is generally thought to be 20-30 years, unlike that of the western pearlshell whose life may span 100 years or more (Toy 1998). The primary factors affecting length-to-age relationships are temperature of water and availability of foodstuff (Toy 1998). The age-to-shell length relationships for native mussel in the Columbia River have not been previously described. In addition, individual mussels that are relatively small ( $\sim 30 \mathrm{~mm}$ or less) were not expected to be found using the techniques employed for these surveys. Their absence from our sample limits the ability to interpret the population structure as a whole. However, assuming individual mussels $50 \mathrm{~mm}$ long or longer were equally detectable during these surveys, some population-level inferences can be made. All three Anodonta species appeared to have similar bell-shaped distributions of shell length and indicate that the highest survival rates are individuals greater than $100 \mathrm{~mm}$ and less than $130 \mathrm{~mm}$ long. The shell length distribution shown in Figure 4.9 may be an indication of extensive early life-stage mortality or low reproductive success (at least for shell lengths of 50 to $100 \mathrm{~mm}$ ). This bell-curve distribution may indicate that the population as a whole may be declining because reproductive recruitment (assuming no emigration into the population) is relatively low. Potential causes of these demographic patterns include reduction of suitable hosts (fishes) for glochidial life-stage and lack of suitable habitat for juveniles (i.e., desiccation of juvenile rearing areas due to water level fluctuations during critical juvenile life-stage periods, ambient water temperatures above tolerance levels, or reduced adult fitness). Poor water quality would not be considered a negative factor to mussel reproduction in the Hanford Reach based on water quality parameters that meet Washington State surface water quality standards (Poston et al. 2009). The fact that all three species observed along the Hanford Reach were found to have the same demographic structures indicates that the causative factor(s) may be associated with some large-scale event(s). Subsequent monitoring efforts to determine whether the mussel densities or size classes are changing may help address this question. An assessment of juvenile rearing habitat and the reproduction patterns of adult mussels along the Columbia River would also help describe factors affecting the population of mussels along this large-river system.

Survey techniques employed during this effort provided a fast yet accurate approach for characterizing the mussel populations found in this large-river system. The snorkel survey technique is not suitable for detecting juvenile mussels; thus, the datasets presented in this report reflect only current conditions of adult mussels. Observers noted that it was important to ensure that surveys were conducted systematically in the portion of the river located between 1 and $2 \mathrm{~m}$ below the low-water mark at visual survey distances of not more than $1 \mathrm{~m}$. The distributions of mussels along a gradient of water depths were not part of this study. However, field survey teams noted that the mussel density appeared highest in the 1- to 2-m region below the low-water mark.

One key environmental variable affecting the distribution and abundance of mussels along the Hanford Reach is the frequency and duration at which water inundates the shoreline areas (Turner 2004). Inundation of shoreline areas along the Hanford Reach may fluctuate daily and seasonally in response to both natural seasonal cycles and hydroelectric operations at upstream dams on the Columbia River (McMichael et al. 2003; Geist et al. 2006). Water-level fluctuations can reach $\pm 3 \mathrm{~m}$ vertically each day. Stark (2001) found that benthic macroinvertebrates inhabiting substrates periodically exposed by waterlevel fluctuations in the Hanford Reach were severely limited in density and biomass compared to those in substrates (control group) that were continually underwater. Anodonta spp. are known to be vulnerable 
to large and rapid water-level fluctuations if they cannot stay within the wetted zone or burrow into the sediment before desiccating, overheating, or becoming prey to other animals (Nedeau et al. 2009).

In summary, we documented that the three species of Anodonta (California, Oregon, and western floaters) were found inhabiting certain portions of the Hanford Reach in relatively low populations with the exception of a few sections where relatively moderate densities occurred. These sections included near the Hanford town site slough (RM 362.5), near the 100-F Area (RM 365.5-367), and one location upstream of the Vernita Bridge (RM 389). Mussel populations were more likely to be found in the lower portions of the Hanford Reach from the 100-F Area to near Richland. We did not find any live western pearlshell mussels or any live or dead western ridged mussels. We found a total of four mussels likely belonging to the Unionidae family, with morphological characteristics similar to those of the Oregon floater, but which did not fit the general classification of this species. Whether these were slight variations of a known or a previously unidentified species has not been determined. 


\subsection{References}

Brim Box J, D Wolf, J Howard, C O'Brien, D Nez, and D Close. 2004. Distribution and Status of Freshwater Mussels in the Umatilla River System - 2002-2003 Annual Report. DOE/BP-00011402-1, Bonneville Power Administration, Portland, Oregon.

Brim Box J, J Howard, D Wolf, C O’Brien, D Nez, and D Close. 2006. Freshwater mussels (Bivalvia: Unionoida) of the Umatilla and Middle Fork John Day rivers in eastern Oregon. Northwest Science 80(2):95-107.

Coutant CC and CD Becker. 1970. Growth of the Columbia River Lanxt, Fisherola nuttalli (Haldeman), in Normal and Reactor-Warmed Water. BNWL-1537, Battelle, Pacific Northwest Laboratories, Richland, Washington.

Dauble DD, TP Hanrahan, DR Geist, and MJ Parsley. 2003. Impacts of the Columbia River hydroelectric system on main-stem habitats of fall Chinook salmon. North American Journal of Fisheries Management 23(3):641-659.

Dauble DD and DR Geist. 2000. Comparison of mainstem spawning habitats for two populations of fall Chinook salmon in the Columbia River Basin. Regulated Rivers: Research and Management $16: 345-361$.

Dauble DD and DG Watson. 1997. Status of fall Chinook salmon populations in the mid-Columbia River, 1948-1992. North American Journal of Fisheries Management 17:283-300.

DART. 2009. Columbia River Data Access in Real Time. Columbia Basin Research, School of Aquatic \& Fishery Sciences, University of Washington, Seattle. Available at http://www.cbr.washington.edu/dart/ (December 2009).

DOE-RL. 2006. Aquatic and Riparian Receptor Impact Information for the 100-NR-2 Groundwater Operable Unit. DOE/RL-2006-26, Draft A, U.S. Department of Energy Richland Operations Office, Richland, Washington.

Frest TJ and EJ Johannes. 1992. Effects of the March 1992 Drawdown on the Freshwater Mollusks of the Lower Granite Lake Area, Snake River, SE WA\& W ID. Deixis Consultants, Seattle, Washington.

Frest TJ and EJ Johannes. 1993. Mollusk Survey of the Hanford Site, Benton and Franklin Counties, Washington. PNL-8653, Pacific Northwest Laboratory, Richland, Washington.

Frest TJ and EJ Johannes. 1995. Interior Columbia Basin Mollusk Species of Special Concern. Deixis Consultants, Seattle, Washington.

Geist D, EV Arntzen, TP Hanrahan, Y-J Chien, CJ Murray, WA Perkins, MC Richmond, and Y Xie. 2006. Spawning Habitat Studies of Hanford Reach Fall Chinook Salmon (Oncorhynchus tshawytscha). Document ID\# P110555, Bonneville Power Administration, Portland, Oregon. 
Helmstetler H and DL Cowles. 2008. Population characteristics of native freshwater mussels in the midColumbia and Clearwater rivers, Washington State. Northwest Science 82(3):211-221.

Lydeard C, RH Cowie, WF Ponder, AE Bogan, P Bouchet, SA Clark, KS Cummings TJ Frest, O Gargominy, DG Herbert, R Hershler, KE Perez, B Roch, M Seddon, EE Strong, and FG Thompson. 2004. The global decline of nonmarine molluscs. BioScience 54(4):321-330.

Marceau TE, and JJ Sharpe. 2002. Excavation Report for Archeological Sites 45-BN-888 and 45-BN-606 on the Hanford Site, Richland, Washington. BHI-01645 Rev. 0, Bechtel Hanford, Inc., Richland, Washington.

McGavock EH, WD Wiggins, RL Blaz, PR Boucher, LL Reed, and ML Smith. 1987. Water Resources Data, Washington, Water Year 1985. Water Data Report WA-85-1, U.S. Geological Survey, Tacoma, Washington.

McMichael GA, DR Geist, TP Hanrahan, EV Arntzen, RP Mueller, RA Moursund, JA Carter, JM Becker, CA McKinstry, WA Perkins, DD Dauble, TM Degerman, JR Skalski, RL Townsend, BB James, and DR Thornhill. 2003. Chinook Salmon in the Priest Rapids Project. PNWD-3243, prepared by BattellePacific Northwest Division for the Public Utility District No. 2 of Grant County, Ephrata, Washington.

NatureServe. 2009. NatureServe Explorer: An Online Encyclopedia of Life. Version 7.1. NatureServe, Arlington, Virginia. Available at http://www.natureserve.org/explorer (June 2010).

Nedeau EJ, AK Smith, J Stone, and S Jepsen. 2009. Freshwater Mussels of the Pacific Northwest. 2nd edition. The Xerces Society for Invertebrate Conservation, Portland, Oregon. Available at http://www.xerces.org/identification-guides/ (June 2010).

Neitzel DA and TJ Frest. 1989. Survey of Columbia River Basin Streams for Giant Columbia River Spire Snail Flumincola columbiana and Great Columbia River Limpet Fisherola nuttalli. PNL-7103, Pacific Northwest Laboratory, Richland, Washington.

Neitzel DA and TJ Frest. 1992. Survey of Columbia River Basin Streams for Columbia Pebblesnail Fluminicola columbiana and Shortface Lanx Fisherola nuttalli. PNL-8229, Pacific Northwest Laboratory, Richland, Washington.

Newell RL. 2003. Aquatic macroinvertebrates. Chapter 8 in Biodiversity Studies of the Hanford SiteFinal Report: 2002-2003, JR Evans, MP Lih, and PW Dunwiddie (eds), pp. 73-96. The Nature Conservancy, Seattle, Washington.

Platts WS, WF Megahan, and HW Minshall. 1983. Methods for Evaluating Stream, Riparian, and Biotic Conditions. General Technical Report INT-138, U.S. Forest Service, Intermountain Forest and Range Experiment Station, Ogden, Utah.

Poston TM, JP Duncan, and RL Dirkes (eds). 2009. Hanford Site Environmental Report for Calendar Year 2008. PNNL-18427, Pacific Northwest National Laboratory, Richland, Washington. 
Rensel J. 1992. Analysis of Stream Conditions in Upper Bear Creek, Washington. Rensel Associates Aquatic Sciences, Arlington, Washington.

Rosenberg DM and VH Resh. 1992. Introduction to freshwater biomonitoring and benthic macroinvertebrates. Chapter 1 in Freshwater Monitoring and Benthic Macroinvertebrates, DM Rosenberg and VH Resh (eds), pp. 1-9. Springer-Verlag, New York.

Stark EJ. 2001. Effects of Water Level Fluctuations on Benthic Macroinvertebrates in the Hanford Reach, Columbia River. Master's thesis, University of Idaho, Moscow.

Strayer DL and DR Smith. 2003. A Guide to Sampling Freshwater Mussel Populations. Monograph 8, American Fisheries Society, Bethesda, Maryland.

Toy KA. 1998. Growth, Reproduction, and Habitat Preference of the Freshwater Mussel Margaritifera margaritifera falcata in Western Washington. Master's thesis, University of Washington, Seattle.

Turgeon DD, JF Quinn Jr, AE Bogan, EV Coan, FG Hochberg, WG Lyons, PM Mikkelsen, RJ Neves, CFE Roper, G Rosenberg, B Roth, A Scheltema, FG Thompson, M Vecchione, and JD Williams. 1998. Common and Scientific Names of Aquatic Invertebrates from the United States and Canada: Mollusks. 2nd edition. Special Publication 26, American Fisheries Society, Bethesda, Maryland.

Turner GK 2004. Factors Affecting the Distribution of Vascular Vegetation, Non-Vegetated Substrate, Periphyton, Asiatic Clams, Crayfish, and Sculpin in the Hanford Reach of the Columbia River. Master's thesis, Eastern Washington University, Cheney.

Vannote RL and GW Minshall. 1982. Fluvial processes and local lithology controlling abundance, structure, and composition of mussel beds. Proceedings of the National Academy of Sciences 79:4103-4107. 


\section{Appendix}

\section{Anodonta Sightings in the Hanford Reach, 2004}




\begin{tabular}{|c|c|c|c|c|c|c|c|c|c|c|c|c|}
\hline \multirow[b]{2}{*}{ Date } & \multirow[b]{2}{*}{ General Area } & \multirow[b]{2}{*}{$\begin{array}{l}\text { River } \\
\text { Class }\end{array}$} & \multicolumn{6}{|c|}{ Habitat Characteristics } & \multirow[b]{2}{*}{$\begin{array}{c}\text { Transect } \\
\text { Length (m) }\end{array}$} & \multirow[b]{2}{*}{$\begin{array}{c}\text { Transect } \\
\text { Width (m) }\end{array}$} & \multicolumn{2}{|c|}{ Taxonomy } \\
\hline & & & $\begin{array}{l}\text { Dominant } \\
\text { Substrate } \\
\text { Class (1-4) }\end{array}$ & $\begin{array}{l}\text { Dominant } \\
\text { Substrate } \\
\text { Size }(\mathrm{mm})\end{array}$ & $\begin{array}{l}\text { Subdominant } \\
\text { Substrate } \\
\text { Class }(1-4)\end{array}$ & $\begin{array}{c}\text { Subdominant } \\
\text { Substrate Size } \\
(\mathrm{mm})\end{array}$ & $\begin{array}{c}\text { Embed. } \\
\text { Class (1-4) }\end{array}$ & $\begin{array}{l}\text { Aquatic } \\
\text { Vegetation } \\
\text { Class (1-4) }\end{array}$ & & & Genera & Species \\
\hline $9 / 10 / 2004$ & $100-\mathrm{F}$ & $\mathrm{IAC}^{(\mathrm{a})}$ & 2 & 128 & 1 & 4 & 2 & 2 & 62 & 4 & - & - \\
\hline 9/10/2004 & $100-\mathrm{F}$ & IAC & 1 & $<6$ & 1 & $<6$ & 4 & 1 & 25 & 4 & - & - \\
\hline $9 / 10 / 2004$ & $100-\mathrm{F}$ & IAC & 2 & 98 & 2 & 49 & 1 & 1 & 280 & 4 & - & - \\
\hline $9 / 10 / 2004$ & White Bluffs & $\mathrm{SBC}^{(\mathrm{b})}$ & 1 & $<6$ & 2 & 37 & 4 & 1 & 140 & 4 & Anodonta & - \\
\hline $9 / 10 / 2004$ & White Bluffs & SBC & 1 & $<6$ & 2 & 37 & 4 & 1 & 140 & 4 & Anodonta & - \\
\hline $9 / 10 / 2004$ & White Bluffs & SBC & 1 & $<6$ & 2 & 37 & 4 & 1 & 140 & 4 & Anodonta & - \\
\hline $9 / 10 / 2004$ & White Bluffs & SBC & 1 & $<6$ & 2 & 37 & 4 & 1 & 140 & 4 & Anodonta & - \\
\hline $9 / 10 / 2004$ & White Bluffs & SBC & 1 & $<6$ & 2 & 37 & 4 & 1 & 140 & 4 & Anodonta & - \\
\hline $9 / 10 / 2004$ & White Bluffs & SBC & 1 & $<6$ & 2 & 37 & 4 & 1 & 140 & 4 & Anodonta & - \\
\hline $9 / 10 / 2004$ & White Bluffs & SBC & 1 & $<6$ & 2 & 37 & 4 & 1 & 140 & 4 & Anodonta & - \\
\hline $9 / 10 / 2004$ & $100-\mathrm{F}$ & IAC & 1 & $<6$ & 2 & 24 & 4 & 2 & 450 & 2 & Anodonta & - \\
\hline $9 / 10 / 2004$ & $300-A$ & IAC & 1 & $<6$ & 4 & $>305$ & 4 & 4 & 210 & 4 & - & - \\
\hline $9 / 13 / 2004$ & Vernita & $\mathrm{RC}^{(\mathrm{c})}$ & 2 & 127 & 2 & 43 & 2 & 1 & 152 & 4 & - & - \\
\hline $9 / 13 / 2004$ & Vernita & $\mathrm{RC}$ & 2 & 119 & 2 & 37 & 3 & 2 & 120 & 4 & Anodonta & - \\
\hline $9 / 13 / 2004$ & Vernita & $\mathrm{RC}$ & 2 & 119 & 2 & 37 & 3 & 2 & 120 & 4 & Anodonta & - \\
\hline $9 / 13 / 2004$ & Vernita & $\mathrm{RC}$ & 2 & 119 & 2 & 37 & 3 & 2 & 120 & 4 & Anodonta & - \\
\hline $9 / 13 / 2004$ & Vernita & $\mathrm{RC}$ & 2 & 119 & 2 & 37 & 3 & 2 & 120 & 4 & Anodonta & - \\
\hline $9 / 13 / 2004$ & Vernita & $\mathrm{RC}$ & 2 & 119 & 2 & 37 & 3 & 2 & 120 & 4 & Anodonta & - \\
\hline $9 / 13 / 2004$ & Vernita & $\mathrm{RC}$ & 2 & 119 & 2 & 37 & 3 & 2 & 120 & 4 & Anodonta & - \\
\hline $9 / 13 / 2004$ & Vernita & $\mathrm{RC}$ & 2 & 119 & 2 & 37 & 3 & 2 & 120 & 4 & Anodonta & - \\
\hline $9 / 13 / 2004$ & Vernita & $\mathrm{RC}$ & 2 & 119 & 2 & 37 & 3 & 2 & 120 & 4 & Anodonta & - \\
\hline $9 / 13 / 2004$ & Vernita & $\mathrm{RC}$ & 2 & 119 & 2 & 37 & 3 & 2 & 120 & 4 & Anodonta & - \\
\hline $9 / 13 / 2004$ & Vernita & $\mathrm{RC}$ & 2 & 119 & 2 & 37 & 3 & 2 & 120 & 4 & Anodonta & - \\
\hline $9 / 13 / 2004$ & Vernita & $\mathrm{RC}$ & 2 & 119 & 2 & 37 & 3 & 2 & 120 & 4 & Anodonta & - \\
\hline $9 / 13 / 2004$ & Vernita & $\mathrm{RC}$ & 2 & 119 & 2 & 37 & 3 & 2 & 120 & 4 & Anodonta & - \\
\hline $9 / 13 / 2004$ & Vernita & $\mathrm{RC}$ & 2 & 119 & 2 & 37 & 3 & 2 & 120 & 4 & Anodonta & - \\
\hline $9 / 13 / 2004$ & Vernita & $\mathrm{RC}$ & 2 & 119 & 2 & 37 & 3 & 2 & 120 & 4 & Anodonta & - \\
\hline 9/13/2004 & Vernita & $\mathrm{RC}$ & 2 & 119 & 2 & 37 & 3 & 2 & 120 & 4 & Anodonta & - \\
\hline $9 / 13 / 2004$ & Vernita & $\mathrm{RC}$ & 2 & 119 & 2 & 37 & 3 & 2 & 120 & 4 & Anodonta & - \\
\hline $9 / 13 / 2004$ & Vernita & $\mathrm{RC}$ & 2 & 119 & 2 & 37 & 3 & 2 & 120 & 4 & Anodonta & - \\
\hline $9 / 15 / 2004$ & Vernita & $\mathrm{RC}$ & 2 & 112 & 2 & 48 & 3 & 2 & 150 & 4 & - & - \\
\hline $9 / 15 / 2004$ & Vernita & $\mathrm{RC}$ & 1 & $<6$ & 1 & $<6$ & 4 & 4 & 230 & 4 & Anodonta & - \\
\hline
\end{tabular}




\begin{tabular}{|c|c|c|c|c|c|c|c|c|c|c|c|c|}
\hline \multirow[b]{2}{*}{ Date } & \multirow[b]{2}{*}{ General Area } & \multirow[b]{2}{*}{$\begin{array}{l}\text { River } \\
\text { Class }\end{array}$} & \multicolumn{6}{|c|}{ Habitat Characteristics } & \multirow[b]{2}{*}{$\begin{array}{c}\text { Transect } \\
\text { Length (m) }\end{array}$} & \multirow[b]{2}{*}{$\begin{array}{c}\text { Transect } \\
\text { Width (m) }\end{array}$} & \multicolumn{2}{|c|}{ Taxonomy } \\
\hline & & & $\begin{array}{l}\text { Dominant } \\
\text { Substrate } \\
\text { Class (1-4) }\end{array}$ & $\begin{array}{l}\text { Dominant } \\
\text { Substrate } \\
\text { Size }(\mathrm{mm})\end{array}$ & $\begin{array}{l}\text { Subdominant } \\
\text { Substrate } \\
\text { Class (1-4) }\end{array}$ & $\begin{array}{l}\text { Subdominant } \\
\text { Substrate Size } \\
(\mathrm{mm})\end{array}$ & $\begin{array}{c}\text { Embed. } \\
\text { Class (1-4) }\end{array}$ & $\begin{array}{c}\text { Aquatic } \\
\text { Vegetation } \\
\text { Class (1-4) }\end{array}$ & & & Genera & Species \\
\hline $9 / 15 / 2004$ & Vernita & $\mathrm{RC}$ & 1 & $<6$ & 1 & $<6$ & 4 & 4 & 230 & 4 & Anodonta & - \\
\hline $9 / 15 / 2004$ & Vernita & $\mathrm{RC}$ & 1 & $<6$ & 1 & $<6$ & 4 & 4 & 230 & 4 & Anodonta & - \\
\hline $9 / 15 / 2004$ & Vernita & $\mathrm{RC}$ & 1 & $<6$ & 1 & $<6$ & 4 & 4 & 230 & 4 & Anodonta & - \\
\hline $9 / 15 / 2004$ & Vernita & $\mathrm{RC}$ & 1 & $<6$ & 1 & $<6$ & 4 & 4 & 230 & 4 & Anodonta & - \\
\hline $9 / 15 / 2004$ & Vernita & $\mathrm{RC}$ & 1 & $<6$ & 1 & $<6$ & 4 & 4 & 230 & 4 & Anodonta & - \\
\hline $9 / 15 / 2004$ & Vernita & $\mathrm{RC}$ & 1 & $<6$ & 1 & $<6$ & 4 & 4 & 230 & 4 & Anodonta & - \\
\hline $9 / 15 / 2004$ & Vernita & $\mathrm{RC}$ & 1 & $<6$ & 1 & $<6$ & 4 & 4 & 230 & 4 & Anodonta & - \\
\hline $9 / 15 / 2004$ & Vernita & $\mathrm{RC}$ & 1 & $<6$ & 1 & $<6$ & 4 & 4 & 230 & 4 & Anodonta & - \\
\hline $9 / 15 / 2004$ & Vernita & $\mathrm{RC}$ & 1 & $<6$ & 1 & $<6$ & 4 & 4 & 230 & 4 & Anodonta & - \\
\hline $9 / 15 / 2004$ & Vernita & $\mathrm{RC}$ & 1 & $<6$ & 1 & $<6$ & 4 & 4 & 230 & 4 & Anodonta & - \\
\hline $9 / 15 / 2004$ & Vernita & $\mathrm{RC}$ & 1 & $<6$ & 1 & $<6$ & 4 & 4 & 230 & 4 & Anodonta & - \\
\hline $9 / 15 / 2004$ & Vernita & $\mathrm{RC}$ & 2 & 84 & 2 & 22 & 2 & 1 & 275 & 4 & - & - \\
\hline $9 / 15 / 2004$ & Vernita & $\mathrm{RC}$ & 2 & 56 & 2 & 9 & 2 & 1 & 115 & 4 & - & - \\
\hline $9 / 16 / 2004$ & $100-\mathrm{F}$ & $\mathrm{RC}$ & 2 & 136 & 2 & 46 & 2 & 1 & 103 & 4 & - & - \\
\hline $9 / 16 / 2004$ & White Bluffs & IAC & 2 & 95 & 2 & 29 & 2 & 1 & 115 & 4 & - & - \\
\hline $9 / 16 / 2004$ & White Bluffs & IAC & 2 & 143 & 2 & 74 & 1 & 1 & 120 & 4 & - & - \\
\hline $9 / 16 / 2004$ & $100-\mathrm{H}$ & IAC & 2 & 152 & 2 & 40 & 4 & 4 & 204 & 4 & - & - \\
\hline $9 / 16 / 2004$ & $100-\mathrm{H}$ & IAC & 2 & 113 & 2 & 34 & 3 & 2 & 165 & 4 & Anodonta & - \\
\hline $9 / 17 / 2004$ & White Bluffs & $\mathrm{RC}$ & 2 & 99 & 2 & 31 & 3 & 3 & 144 & 4 & - & - \\
\hline $9 / 17 / 2004$ & $100-\mathrm{F}$ & $\mathrm{RC}$ & 3 & 154 & 2 & 21 & 2 & 1 & 178 & 4 & - & - \\
\hline $9 / 17 / 2004$ & $100-\mathrm{F}$ & SB & 2 & 100 & 2 & 32 & 4 & 4 & 112 & 4 & Anodonta & - \\
\hline $9 / 17 / 2004$ & Hanford town site & IAC & 2 & 29 & 2 & 111 & 2 & 2 & 299 & 4 & - & - \\
\hline $9 / 20 / 2004$ & Hanford town site & $\mathrm{SBC}$ & 1 & $<6$ & 2 & 73 & 4 & 2 & 125 & 4 & Anodonta & - \\
\hline $9 / 20 / 2004$ & Hanford town site & SBC & 1 & $<6$ & 2 & 73 & 4 & 2 & 125 & 4 & Anodonta & - \\
\hline $9 / 20 / 2004$ & Hanford town site & SBC & 1 & $<6$ & 2 & 73 & 4 & 2 & 125 & 4 & Anodonta & - \\
\hline $9 / 20 / 2004$ & Hanford town site & SBC & 1 & $<6$ & 2 & 73 & 4 & 2 & 125 & 4 & Anodonta & - \\
\hline $9 / 20 / 2004$ & Hanford town site & SBC & 1 & $<6$ & 2 & 73 & 4 & 2 & 125 & 4 & Anodonta & - \\
\hline $9 / 20 / 2004$ & Hanford town site & SBC & 1 & $<6$ & 2 & 73 & 4 & 2 & 125 & 4 & Anodonta & - \\
\hline $9 / 20 / 2004$ & Hanford town site & $\mathrm{RC}$ & 2 & 81 & 2 & 24 & 3 & 1 & 150 & 4 & - & - \\
\hline $9 / 20 / 2004$ & Hanford town site & $\mathrm{RC}$ & 2 & 125 & 2 & 52 & 3 & 3 & 134 & 4 & - & - \\
\hline $9 / 20 / 2004$ & Hanford town site & $\mathrm{RC}$ & 2 & 129 & 2 & 68 & 2 & 1 & 130 & 4 & - & - \\
\hline $9 / 21 / 2004$ & Vernita & $\mathrm{RC}$ & 3 & 190 & 2 & 50 & 1 & 1 & 154 & 4 & - & - \\
\hline
\end{tabular}




\begin{tabular}{|c|c|c|c|c|c|c|c|c|c|c|c|c|}
\hline \multirow[b]{2}{*}{ Date } & \multirow[b]{2}{*}{ General Area } & \multirow[b]{2}{*}{$\begin{array}{l}\text { River } \\
\text { Class }\end{array}$} & \multicolumn{6}{|c|}{ Habitat Characteristics } & \multirow[b]{2}{*}{$\begin{array}{l}\text { Transect } \\
\text { Length (m) }\end{array}$} & \multirow[b]{2}{*}{$\begin{array}{c}\text { Transect } \\
\text { Width (m) }\end{array}$} & \multicolumn{2}{|c|}{ Taxonomy } \\
\hline & & & $\begin{array}{c}\text { Dominant } \\
\text { Substrate } \\
\text { Class (1-4) }\end{array}$ & $\begin{array}{c}\text { Dominant } \\
\text { Substrate } \\
\text { Size }(\mathrm{mm})\end{array}$ & $\begin{array}{l}\text { Subdominant } \\
\text { Substrate } \\
\text { Class }(1-4)\end{array}$ & $\begin{array}{l}\text { Subdominant } \\
\text { Substrate Size } \\
(\mathrm{mm})\end{array}$ & $\begin{array}{c}\text { Embed. } \\
\text { Class (1-4) }\end{array}$ & $\begin{array}{c}\text { Aquatic } \\
\text { Vegetation } \\
\text { Class (1-4) }\end{array}$ & & & Genera & Species \\
\hline $9 / 21 / 2004$ & Vernita & IAC & 2 & 132 & 2 & 23 & 1 & 1 & 205 & 4 & - & - \\
\hline $9 / 21 / 2004$ & Vernita & $\mathrm{RC}$ & 2 & 121 & 1 & $<6$ & 4 & 2 & 292 & 4 & Anodonta & - \\
\hline $9 / 21 / 2004$ & Vernita & $\mathrm{RC}$ & 2 & 121 & 1 & $<6$ & 4 & 2 & 292 & 4 & Anodonta & - \\
\hline $9 / 21 / 2004$ & Vernita & $\mathrm{RC}$ & 2 & 121 & 1 & $<6$ & 4 & 2 & 292 & 4 & Anodonta & - \\
\hline $9 / 21 / 2004$ & Vernita & $\mathrm{RC}$ & 3 & 155 & 2 & 47 & 2 & 1 & 147 & 4 & - & - \\
\hline $9 / 22 / 2004$ & Vernita & $\mathrm{RC}$ & 1 & $<6$ & 2 & - & 4 & 2 & 175 & 4 & Anodonta & - \\
\hline $9 / 22 / 2004$ & Vernita & $\mathrm{RC}$ & 1 & $<6$ & 2 & - & 4 & 2 & 175 & 4 & Anodonta & - \\
\hline $9 / 22 / 2004$ & Vernita & $\mathrm{RC}$ & 1 & $<6$ & 2 & - & 4 & 2 & 175 & 4 & Anodonta & - \\
\hline $9 / 22 / 2004$ & Vernita & $\mathrm{RC}$ & 1 & $<6$ & 2 & - & 4 & 2 & 175 & 4 & Anodonta & - \\
\hline $9 / 22 / 2004$ & Vernita & $\mathrm{RC}$ & 1 & $<6$ & 2 & - & 4 & 2 & 175 & 4 & Anodonta & - \\
\hline $9 / 22 / 2004$ & Vernita & $\mathrm{RC}$ & 1 & $<6$ & 2 & - & 4 & 2 & 175 & 4 & Anodonta & - \\
\hline $9 / 22 / 2004$ & Vernita & $\mathrm{RC}$ & 1 & $<6$ & 2 & - & 4 & 2 & 175 & 4 & Anodonta & - \\
\hline $9 / 22 / 2004$ & Vernita & $\mathrm{RC}$ & 1 & $<6$ & 2 & - & 4 & 2 & 175 & 4 & Anodonta & - \\
\hline $9 / 22 / 2004$ & Vernita & $\mathrm{RC}$ & 1 & $<6$ & 2 & - & 4 & 2 & 175 & 4 & Anodonta & - \\
\hline $9 / 22 / 2004$ & Vernita & $\mathrm{RC}$ & 1 & $<6$ & 2 & - & 4 & 2 & 175 & 4 & Anodonta & - \\
\hline $9 / 22 / 2004$ & Vernita & $\mathrm{RC}$ & 1 & $<6$ & 2 & - & 4 & 2 & 175 & 4 & Anodonta & - \\
\hline $9 / 22 / 2004$ & Vernita & $\mathrm{RC}$ & 1 & $<6$ & 2 & - & 4 & 2 & 175 & 4 & Anodonta & - \\
\hline $9 / 22 / 2004$ & Vernita & $\mathrm{RC}$ & 1 & $<6$ & 2 & - & 4 & 2 & 175 & 4 & Anodonta & - \\
\hline $9 / 22 / 2004$ & Vernita & $\mathrm{RC}$ & 1 & $<6$ & 2 & - & 4 & 2 & 175 & 4 & Anodonta & - \\
\hline $9 / 22 / 2004$ & Vernita & $\mathrm{RC}$ & 1 & $<6$ & 2 & - & 4 & 2 & 175 & 4 & Anodonta & - \\
\hline $9 / 22 / 2004$ & Vernita & $\mathrm{RC}$ & 1 & $<6$ & 2 & - & 4 & 2 & 175 & 4 & Anodonta & - \\
\hline $9 / 22 / 2004$ & Vernita & $\mathrm{RC}$ & 1 & $<6$ & 2 & - & 4 & 2 & 175 & 4 & Anodonta & - \\
\hline $9 / 22 / 2004$ & Vernita & $\mathrm{RC}$ & 1 & $<6$ & 2 & - & 4 & 2 & 175 & 4 & Anodonta & - \\
\hline $9 / 22 / 2004$ & Vernita & $\mathrm{RC}$ & 1 & $<6$ & 2 & - & 4 & 2 & 175 & 4 & Anodonta & - \\
\hline $9 / 22 / 2004$ & Vernita & $\mathrm{RC}$ & 1 & $<6$ & 2 & - & 4 & 2 & 175 & 4 & Anodonta & - \\
\hline $9 / 22 / 2004$ & Vernita & $\mathrm{RC}$ & 1 & $<6$ & 2 & - & 4 & 2 & 175 & 4 & Anodonta & - \\
\hline $9 / 22 / 2004$ & Vernita & $\mathrm{RC}$ & 1 & $<6$ & 2 & - & 4 & 2 & 175 & 4 & Anodonta & - \\
\hline $9 / 22 / 2004$ & Vernita & $\mathrm{RC}$ & 1 & $<6$ & 2 & - & 4 & 2 & 175 & 4 & Anodonta & - \\
\hline $9 / 22 / 2004$ & Vernita & $\mathrm{RC}$ & 1 & $<6$ & 2 & - & 4 & 2 & 175 & 4 & Anodonta & - \\
\hline $9 / 22 / 2004$ & Vernita & $\mathrm{RC}$ & 1 & $<6$ & 2 & - & 4 & 2 & 175 & 4 & Anodonta & - \\
\hline $9 / 22 / 2004$ & Vernita & $\mathrm{RC}$ & 1 & $<6$ & 2 & - & 4 & 2 & 175 & 4 & Anodonta & - \\
\hline $9 / 23 / 2004$ & Hanford town site & $\mathrm{SBC}$ & 1 & $<6$ & 2 & 94 & 4 & 2 & 315 & 4 & Anodonta & - \\
\hline
\end{tabular}




\begin{tabular}{|c|c|c|c|c|c|c|c|c|c|c|c|c|}
\hline \multirow[b]{2}{*}{ Date } & \multirow[b]{2}{*}{ General Area } & \multirow[b]{2}{*}{$\begin{array}{l}\text { River } \\
\text { Class }\end{array}$} & \multicolumn{6}{|c|}{ Habitat Characteristics } & \multirow[b]{2}{*}{$\begin{array}{c}\text { Transect } \\
\text { Length }(\mathrm{m})\end{array}$} & \multirow[b]{2}{*}{$\begin{array}{c}\text { Transect } \\
\text { Width (m) }\end{array}$} & \multicolumn{2}{|c|}{ Taxonomy } \\
\hline & & & $\begin{array}{c}\text { Dominant } \\
\text { Substrate } \\
\text { Class (1-4) }\end{array}$ & $\begin{array}{c}\text { Dominant } \\
\text { Substrate } \\
\text { Size }(\mathrm{mm})\end{array}$ & $\begin{array}{l}\text { Subdominant } \\
\text { Substrate } \\
\text { Class }(1-4)\end{array}$ & $\begin{array}{l}\text { Subdominant } \\
\text { Substrate Size } \\
(\mathrm{mm})\end{array}$ & $\begin{array}{c}\text { Embed. } \\
\text { Class (1-4) }\end{array}$ & $\begin{array}{c}\text { Aquatic } \\
\text { Vegetation } \\
\text { Class (1-4) }\end{array}$ & & & Genera & Species \\
\hline $9 / 23 / 2004$ & Hanford town site & SBC & 1 & $<6$ & 2 & 94 & 4 & 2 & 315 & 4 & Anodonta & - \\
\hline 9/23/2004 & Hanford town site & $\mathrm{SBC}$ & 1 & $<6$ & 2 & 94 & 4 & 2 & 315 & 4 & Anodonta & - \\
\hline $9 / 23 / 2004$ & Hanford town site & $\mathrm{SBC}$ & 1 & $<6$ & 2 & 94 & 4 & 2 & 315 & 4 & Anodonta & - \\
\hline 9/23/2004 & Hanford town site & SBC & 1 & $<6$ & 2 & 94 & 4 & 2 & 315 & 4 & Anodonta & - \\
\hline $9 / 23 / 2004$ & Hanford town site & $\mathrm{SBC}$ & 1 & $<6$ & 2 & 94 & 4 & 2 & 315 & 4 & Anodonta & - \\
\hline 9/23/2004 & Hanford town site & $\mathrm{SBC}$ & 1 & $<6$ & 2 & 94 & 4 & 2 & 315 & 4 & Anodonta & - \\
\hline $9 / 23 / 2004$ & Hanford town site & SBC & 1 & $<6$ & 2 & 94 & 4 & 2 & 315 & 4 & Anodonta & - \\
\hline 9/23/2004 & Hanford town site & SBC & 1 & $<6$ & 2 & 94 & 4 & 2 & 315 & 4 & Anodonta & - \\
\hline $9 / 23 / 2004$ & Hanford town site & $\mathrm{SBC}$ & 1 & $<6$ & 2 & 94 & 4 & 2 & 315 & 4 & Anodonta & - \\
\hline $9 / 23 / 2004$ & Hanford town site & $\mathrm{SBC}$ & 1 & $<6$ & 2 & 94 & 4 & 2 & 315 & 4 & Anodonta & - \\
\hline $9 / 23 / 2004$ & Hanford town site & $\mathrm{SBC}$ & 1 & $<6$ & 2 & 94 & 4 & 2 & 315 & 4 & Anodonta & - \\
\hline 9/23/2004 & Hanford town site & $\mathrm{SBC}$ & 1 & $<6$ & 2 & 94 & 4 & 2 & 315 & 4 & Anodonta & - \\
\hline $9 / 23 / 2004$ & Hanford town site & $\mathrm{SBC}$ & 1 & $<6$ & 2 & 94 & 4 & 2 & 315 & 4 & Anodonta & - \\
\hline 9/23/2004 & Hanford town site & $\mathrm{SBC}$ & 1 & $<6$ & 2 & 94 & 4 & 2 & 315 & 4 & Anodonta & - \\
\hline $9 / 23 / 2004$ & Hanford town site & $\mathrm{SBC}$ & 1 & $<6$ & 2 & 94 & 4 & 2 & 315 & 4 & Anodonta & - \\
\hline 9/23/2004 & Hanford town site & $\mathrm{SBC}$ & 1 & $<6$ & 2 & 94 & 4 & 2 & 315 & 4 & Anodonta & - \\
\hline $9 / 23 / 2004$ & Hanford town site & $\mathrm{SBC}$ & 1 & $<6$ & 2 & 94 & 4 & 2 & 315 & 4 & Anodonta & californiensis \\
\hline $9 / 23 / 2004$ & Hanford town site & $\mathrm{SBC}$ & 1 & $<6$ & 2 & 94 & 4 & 2 & 315 & 4 & Anodonta & - \\
\hline $9 / 23 / 2004$ & Hanford town site & $\mathrm{SBC}$ & 1 & $<6$ & 2 & 94 & 4 & 2 & 315 & 4 & Anodonta & - \\
\hline $9 / 23 / 2004$ & Hanford town site & $\mathrm{SBC}$ & 1 & $<6$ & 2 & 94 & 4 & 2 & 315 & 4 & Anodonta & californiensis \\
\hline $9 / 23 / 2004$ & Hanford town site & $\mathrm{SBC}$ & 1 & $<6$ & 2 & 94 & 4 & 2 & 315 & 4 & Anodonta & - \\
\hline $9 / 23 / 2004$ & Hanford town site & $\mathrm{SBC}$ & 1 & $<6$ & 2 & 94 & 4 & 2 & 315 & 4 & Anodonta & - \\
\hline $9 / 23 / 2004$ & Hanford town site & $\mathrm{SBC}$ & 1 & $<6$ & 2 & 94 & 4 & 2 & 315 & 4 & Anodonta & - \\
\hline 9/24/2004 & $300-A$ & IAC & 2 & 91 & 4 & $>305$ & 3 & 3 & 215 & 4 & - & - \\
\hline 9/24/2004 & $100-\mathrm{BC}$ & $\mathrm{SBC}$ & 2 & 122 & 1 & $<6$ & 3 & 2 & 388 & 4 & Anodonta & - \\
\hline $9 / 25 / 2004$ & $100-\mathrm{BC}$ & $\mathrm{SBC}$ & 2 & 122 & 1 & $<7$ & 3 & 2 & 388 & 4 & Anodonta & - \\
\hline 9/26/2004 & $100-\mathrm{BC}$ & $\mathrm{SBC}$ & 2 & 122 & 1 & $<8$ & 3 & 2 & 388 & 4 & Anodonta & - \\
\hline 9/27/2004 & $100-\mathrm{BC}$ & $\mathrm{SBC}$ & 2 & 122 & 1 & $<9$ & 3 & 2 & 388 & 4 & Anodonta & - \\
\hline $10 / 25 / 2004$ & Island 15 & IAC & 2 & 10 & 2 & 60 & 3 & 1 & 57 & 2 & Anodonta & kennerlyi \\
\hline $10 / 25 / 2004$ & Island 15 & IAC & 2 & 10 & 2 & 60 & 3 & 1 & - & - & Anodonta & californiensis \\
\hline $10 / 25 / 2004$ & Island 15 & $\mathrm{IAC}$ & 2 & 10 & 2 & 60 & 3 & 1 & - & - & Anodonta & oregonensis \\
\hline $10 / 25 / 2004$ & Island 15 & IAC & 2 & 10 & 2 & 60 & 3 & 1 & - & - & Margaritinopsis & falcata \\
\hline
\end{tabular}




\begin{tabular}{|c|c|c|c|c|c|c|c|c|c|c|c|c|}
\hline \multirow[b]{2}{*}{ Date } & \multirow[b]{2}{*}{ General Area } & \multirow[b]{2}{*}{$\begin{array}{l}\text { River } \\
\text { Class }\end{array}$} & \multicolumn{6}{|c|}{ Habitat Characteristics } & \multirow[b]{2}{*}{$\begin{array}{c}\text { Transect } \\
\text { Length (m) }\end{array}$} & \multirow[b]{2}{*}{$\begin{array}{c}\text { Transect } \\
\text { Width (m) }\end{array}$} & \multicolumn{2}{|c|}{ Taxonomy } \\
\hline & & & $\begin{array}{c}\text { Dominant } \\
\text { Substrate } \\
\text { Class (1-4) }\end{array}$ & $\begin{array}{l}\text { Dominant } \\
\text { Substrate } \\
\text { Size }(\mathrm{mm})\end{array}$ & $\begin{array}{l}\text { Subdominant } \\
\text { Substrate } \\
\text { Class (1-4) }\end{array}$ & $\begin{array}{c}\text { Subdominant } \\
\text { Substrate Size } \\
(\mathrm{mm})\end{array}$ & $\begin{array}{c}\text { Embed. } \\
\text { Class (1-4) }\end{array}$ & $\begin{array}{c}\text { Aquatic } \\
\text { Vegetation } \\
\text { Class (1-4) }\end{array}$ & & & Genera & Species \\
\hline $10 / 25 / 2004$ & Island 15 & IAC & 2 & 10 & 2 & 60 & 3 & 1 & - & - & Margaritinopsis & falcata \\
\hline $10 / 25 / 2004$ & Island 15 & IAC & 2 & 10 & 2 & 60 & 3 & 1 & - & - & Margaritinopsis & falcata \\
\hline $10 / 25 / 2004$ & Hanford town site & $\mathrm{RC}$ & 1 & $<6$ & 3 & - & 4 & 2 & 50 & 2 & - & - \\
\hline $10 / 25 / 2004$ & Hanford town site & $\mathrm{SBC}$ & 1 & $<6$ & 2 & - & 4 & 2 & 105 & 2 & Anodonta & californiensis \\
\hline $10 / 25 / 2004$ & Hanford town site & $\mathrm{SBC}$ & 1 & $<6$ & 2 & - & 4 & 2 & 105 & 2 & Anodonta & californiensis \\
\hline $10 / 25 / 2004$ & Hanford town site & $\mathrm{SBC}$ & 1 & $<6$ & 2 & - & 4 & 2 & 105 & 2 & Anodonta & californiensis \\
\hline $10 / 25 / 2004$ & Hanford town site & $\mathrm{SBC}$ & 1 & $<6$ & 2 & - & 4 & 2 & 105 & 2 & Anodonta & oregonensis \\
\hline $10 / 25 / 2004$ & Hanford town site & $\mathrm{SBC}$ & 1 & $<6$ & 2 & - & 4 & 2 & 105 & 2 & Anodonta & kennerlyi \\
\hline $10 / 25 / 2004$ & Hanford town site & $\mathrm{SBC}$ & 1 & $<6$ & 2 & - & 4 & 2 & 105 & 2 & Anodonta & californiensis \\
\hline $10 / 25 / 2004$ & Hanford town site & $\mathrm{SBC}$ & 1 & $<6$ & 2 & - & 4 & 2 & 105 & 2 & Anodonta & californensis \\
\hline $10 / 25 / 2004$ & Hanford town site & $\mathrm{SBC}$ & 1 & $<6$ & 2 & - & 4 & 2 & 105 & 2 & Anodonta & kennerlyi \\
\hline $10 / 25 / 2004$ & Hanford town site & $\mathrm{SBC}$ & 1 & $<6$ & 2 & - & 4 & 2 & 105 & 2 & Anodonta & kennerlyi \\
\hline $10 / 25 / 2004$ & Hanford town site & $\mathrm{SBC}$ & 1 & $<6$ & 2 & - & 4 & 2 & 105 & 2 & Anodonta & californiensis \\
\hline $10 / 25 / 2004$ & Hanford town site & $\mathrm{SBC}$ & 1 & $<6$ & 2 & - & 4 & 2 & 105 & 2 & Anodonta & californiensis \\
\hline $10 / 25 / 2004$ & Hanford town site & $\mathrm{SBC}$ & 1 & $<6$ & 2 & - & 4 & 2 & 105 & 2 & Anodonta & kennerlyi \\
\hline $10 / 25 / 2004$ & Hanford town site & $\mathrm{SBC}$ & 1 & $<6$ & 2 & - & 4 & 2 & 105 & 2 & Anodonta & californiensis \\
\hline $10 / 25 / 2004$ & Hanford town site & $\mathrm{SBC}$ & 1 & $<6$ & 2 & - & 4 & 2 & 105 & 2 & Anodonta & californiensis \\
\hline $10 / 25 / 2004$ & Hanford town site & $\mathrm{SBC}$ & 1 & $<6$ & 2 & - & 4 & 2 & 105 & 2 & Anodonta & californensis \\
\hline $10 / 25 / 2004$ & Hanford town site & $\mathrm{SBC}$ & 1 & $<6$ & 2 & - & 4 & 2 & 105 & 2 & Anodonta & californensis \\
\hline $10 / 25 / 2004$ & Hanford town site & $\mathrm{SBC}$ & 1 & $<6$ & 2 & - & 4 & 2 & 105 & 2 & Anodonta & californensis \\
\hline $10 / 25 / 2004$ & Hanford town site & $\mathrm{SBC}$ & 1 & $<6$ & 2 & - & 4 & 2 & 105 & 2 & Anodonta & californensis \\
\hline $10 / 25 / 2004$ & White Bluffs & $\mathrm{SBC}$ & 1 & $<6$ & 2 & - & 4 & 2 & - & - & Anodonta & oregonensis \\
\hline $10 / 25 / 2004$ & White Bluffs & $\mathrm{SBC}$ & 1 & $<6$ & 2 & - & 4 & 2 & - & - & Anodonta & californensis \\
\hline $10 / 25 / 2004$ & White Bluffs & $\mathrm{SBC}$ & 1 & $<6$ & 2 & - & 4 & 2 & - & - & Anodonta & kennerlyi \\
\hline $10 / 25 / 2004$ & White Bluffs & $\mathrm{SBC}$ & 1 & $<6$ & 2 & - & 4 & 2 & - & - & Anodonta & californensis \\
\hline $10 / 25 / 2004$ & White Bluffs & $\mathrm{SBC}$ & 1 & $<6$ & 2 & - & 4 & 2 & - & - & Anodonta & californensis \\
\hline $10 / 25 / 2004$ & White Bluffs & $\mathrm{SBC}$ & 1 & $<6$ & 2 & - & 4 & 2 & - & - & Anodonta & oregonensis \\
\hline $10 / 25 / 2004$ & White Bluffs & $\mathrm{SBC}$ & 1 & $<6$ & 2 & - & 4 & 2 & - & - & Anodonta & californensis \\
\hline $10 / 25 / 2004$ & White Bluffs & $\mathrm{SBC}$ & 1 & $<6$ & 2 & - & 4 & 2 & - & - & Anodonta & californensis \\
\hline $10 / 25 / 2004$ & White Bluffs & $\mathrm{SBC}$ & 1 & $<6$ & 2 & - & 4 & 2 & 168 & 2 & Anodonta & californensis \\
\hline $10 / 25 / 2004$ & White Bluffs & $\mathrm{SBC}$ & 1 & $<6$ & 2 & - & 4 & 2 & 168 & 2 & Anodonta & kennerlyi \\
\hline $10 / 25 / 2004$ & White Bluffs & $\mathrm{SBC}$ & 1 & $<6$ & 2 & - & 4 & 2 & 168 & 2 & Anodonta & californensis \\
\hline
\end{tabular}




\begin{tabular}{|c|c|c|c|c|c|c|c|c|c|c|c|c|}
\hline \multirow[b]{2}{*}{ Date } & \multirow[b]{2}{*}{ General Area } & \multirow[b]{2}{*}{$\begin{array}{l}\text { River } \\
\text { Class }\end{array}$} & \multicolumn{6}{|c|}{ Habitat Characteristics } & \multirow[b]{2}{*}{$\begin{array}{c}\text { Transect } \\
\text { Length (m) }\end{array}$} & \multirow[b]{2}{*}{$\begin{array}{c}\text { Transect } \\
\text { Width (m) }\end{array}$} & \multicolumn{2}{|c|}{ Taxonomy } \\
\hline & & & $\begin{array}{c}\text { Dominant } \\
\text { Substrate } \\
\text { Class (1-4) }\end{array}$ & $\begin{array}{l}\text { Dominant } \\
\text { Substrate } \\
\text { Size }(\mathrm{mm})\end{array}$ & $\begin{array}{l}\text { Subdominant } \\
\text { Substrate } \\
\text { Class (1-4) }\end{array}$ & $\begin{array}{c}\text { Subdominant } \\
\text { Substrate Size } \\
(\mathrm{mm})\end{array}$ & $\begin{array}{c}\text { Embed. } \\
\text { Class (1-4) }\end{array}$ & $\begin{array}{l}\text { Aquatic } \\
\text { Vegetation } \\
\text { Class (1-4) }\end{array}$ & & & Genera & Species \\
\hline $10 / 25 / 2004$ & White Bluffs & $\mathrm{SBC}$ & 1 & $<6$ & 2 & - & 4 & 2 & 168 & 2 & Anodonta & californensis \\
\hline $10 / 25 / 2004$ & White Bluffs & $\mathrm{SBC}$ & 1 & $<6$ & 2 & - & 4 & 2 & 168 & 2 & Anodonta & californensis \\
\hline $10 / 25 / 2004$ & White Bluffs & $\mathrm{SBC}$ & 1 & $<6$ & 2 & - & 4 & 2 & 168 & 2 & Anodonta & kennerlyi \\
\hline $10 / 25 / 2004$ & White Bluffs & $\mathrm{SBC}$ & 1 & $<6$ & 2 & - & 4 & 2 & 168 & 2 & Anodonta & californensis \\
\hline $10 / 25 / 2004$ & White Bluffs & $\mathrm{SBC}$ & 1 & $<6$ & 2 & - & 4 & 2 & 168 & 2 & Anodonta & californensis \\
\hline $10 / 25 / 2004$ & White Bluffs & $\mathrm{SBC}$ & 1 & $<6$ & 2 & - & 4 & 2 & 168 & 2 & Anodonta & kennerlyi \\
\hline $10 / 25 / 2004$ & White Bluffs & $\mathrm{SBC}$ & 1 & $<6$ & 2 & - & 4 & 2 & 168 & 2 & Anodonta & californensis \\
\hline $10 / 25 / 2004$ & White Bluffs & $\mathrm{SBC}$ & 1 & $<6$ & 2 & - & 4 & 2 & 168 & 2 & Anodonta & oregonensis \\
\hline $10 / 26 / 2004$ & Priest Rapids & IAC & 2 & 42 & 2 & 95 & 2 & 4 & 97 & 2 & Anodonta & kennerlyi \\
\hline $10 / 26 / 2004$ & Priest Rapids & IAC & 2 & 42 & 2 & 95 & 2 & 4 & 97 & 2 & Anodonta & oregonensis \\
\hline $10 / 26 / 2004$ & Priest Rapids & $\mathrm{RC}$ & 2 & 88 & 4 & bed rock & 2 & 2 & - & - & Anodonta & kennerlyi \\
\hline $10 / 26 / 2004$ & Priest Rapids & $\mathrm{RC}$ & 2 & 88 & 4 & bed rock & 2 & 2 & - & - & Anodonta & oregonensis \\
\hline $10 / 26 / 2004$ & Priest Rapids & $\mathrm{RC}$ & 2 & 88 & 4 & bed rock & 2 & 2 & - & - & Anodonta & oregonensis \\
\hline $10 / 26 / 2004$ & Priest Rapids & $\mathrm{RC}$ & 2 & 88 & 4 & bed rock & 2 & 2 & - & - & Anodonta & oregonensis \\
\hline $10 / 26 / 2004$ & Priest Rapids & $\mathrm{RC}$ & 2 & 88 & 4 & bed rock & 2 & 2 & - & - & Anodonta & oregonensis \\
\hline $10 / 26 / 2004$ & Priest Rapids & $\mathrm{RC}$ & 2 & 88 & 4 & bed rock & 2 & 2 & - & - & Anodonta & oregonensis \\
\hline $10 / 26 / 2004$ & Priest Rapids & $\mathrm{RC}$ & 2 & 88 & 4 & bed rock & 2 & 2 & - & - & Anodonta & kennerlyi \\
\hline $10 / 26 / 2004$ & Priest Rapids & $\mathrm{RC}$ & 2 & 88 & 4 & bed rock & 2 & 2 & - & - & Anodonta & oregonensis \\
\hline $10 / 26 / 2004$ & Priest Rapids & $\mathrm{RC}$ & 2 & 88 & 4 & bed rock & 2 & 2 & - & - & Anodonta & oregonensis \\
\hline $10 / 26 / 2004$ & $100-\mathrm{D}$ & $\mathrm{RC}$ & 1 & $<6$ & 2 & 88 & 4 & 2 & 80 & 2 & - & - \\
\hline $10 / 26 / 2004$ & White Bluffs & IAC & 2 & 10 & 1 & $<6$ & 3 & 2 & 80 & 2 & Anodonta & kennerlyi \\
\hline $10 / 26 / 2004$ & White Bluffs & IAC & 2 & 10 & 1 & $<6$ & 3 & 2 & 80 & 2 & Anodonta & kennerlyi \\
\hline $10 / 26 / 2004$ & $100-\mathrm{D}$ & IAC & 2 & 25 & 2 & 68 & 3 & 3 & 101 & 2 & Anodonta & - \\
\hline $10 / 26 / 2004$ & $100-\mathrm{D}$ & IAC & 2 & 25 & 2 & 68 & 3 & 3 & 101 & 2 & Anodonta & kennerlyi \\
\hline $10 / 26 / 2004$ & $100-\mathrm{D}$ & IAC & 2 & 25 & 2 & 68 & 3 & 3 & 101 & 2 & Margaritinopsis & falcata \\
\hline $10 / 27 / 2004$ & Vernita Bridge & $\mathrm{RC}$ & 2 & 131 & 2 & 40 & 3 & 2 & 276 & 2 & Anodonta & kennerlyi \\
\hline $10 / 27 / 2004$ & Vernita Bridge & $\mathrm{RC}$ & 2 & 131 & 2 & 40 & 3 & 2 & 276 & 2 & Anodonta & oregonensis \\
\hline $10 / 27 / 2004$ & Coyote Rapids & $\mathrm{RC}$ & 2 & 91 & 2 & 17 & 3 & 3 & 150 & 2 & Anodonta & oregonensis \\
\hline $10 / 27 / 2004$ & $100-\mathrm{K}$ & $\mathrm{RC}$ & 2 & 85 & 2 & 24 & 4 & 3 & 103 & 2 & Anodonta & kennerlyi \\
\hline $10 / 27 / 2004$ & $100-K$ & $\mathrm{RC}$ & 2 & 85 & 2 & 24 & 4 & 3 & 103 & 2 & Anodonta & kennerlyi \\
\hline $10 / 27 / 2004$ & $100-\mathrm{K}$ & $\mathrm{RC}$ & 2 & 85 & 2 & 24 & 4 & 3 & 103 & 2 & Anodonta & kennerlyi \\
\hline $10 / 27 / 2004$ & $100-\mathrm{K}$ & $\mathrm{RC}$ & 2 & 85 & 2 & 24 & 4 & 3 & 103 & 2 & Anodonta & kennerlyi \\
\hline
\end{tabular}




\begin{tabular}{|c|c|c|c|c|c|c|c|c|c|c|c|c|}
\hline \multirow[b]{2}{*}{ Date } & \multirow[b]{2}{*}{ General Area } & \multirow[b]{2}{*}{$\begin{array}{l}\text { River } \\
\text { Class }\end{array}$} & \multicolumn{6}{|c|}{ Habitat Characteristics } & \multirow[b]{2}{*}{$\begin{array}{c}\text { Transect } \\
\text { Length (m) }\end{array}$} & \multirow[b]{2}{*}{$\begin{array}{c}\text { Transect } \\
\text { Width (m) }\end{array}$} & \multicolumn{2}{|c|}{ Taxonomy } \\
\hline & & & $\begin{array}{c}\text { Dominant } \\
\text { Substrate } \\
\text { Class }(1-4)\end{array}$ & $\begin{array}{l}\text { Dominant } \\
\text { Substrate } \\
\text { Size }(\mathrm{mm})\end{array}$ & $\begin{array}{l}\text { Subdominant } \\
\text { Substrate } \\
\text { Class (1-4) }\end{array}$ & $\begin{array}{l}\text { Subdominant } \\
\text { Substrate Size } \\
\quad(\mathrm{mm})\end{array}$ & $\begin{array}{c}\text { Embed. } \\
\text { Class (1-4) }\end{array}$ & $\begin{array}{c}\text { Aquatic } \\
\text { Vegetation } \\
\text { Class (1-4) }\end{array}$ & & & Genera & Species \\
\hline $10 / 27 / 2004$ & $100-\mathrm{K}$ & $\mathrm{RC}$ & 2 & 85 & 2 & 24 & 4 & 3 & 103 & 2 & Anodonta & oregonensis \\
\hline $10 / 27 / 2004$ & $100-\mathrm{K}$ & $\mathrm{RC}$ & 2 & 85 & 2 & 24 & 4 & 3 & 103 & 2 & Anodonta & kennerlyi \\
\hline $10 / 27 / 2004$ & $100-\mathrm{K}$ & $\mathrm{RC}$ & 2 & 85 & 2 & 24 & 4 & 3 & 103 & 2 & Anodonta & kennerlyi \\
\hline $10 / 27 / 2004$ & $100-\mathrm{K}$ & $\mathrm{RC}$ & 2 & 85 & 2 & 24 & 4 & 3 & 103 & 2 & Anodonta & kennerlyi \\
\hline $10 / 27 / 2004$ & $100-\mathrm{K}$ & $\mathrm{RC}$ & 2 & 85 & 2 & 24 & 4 & 3 & 103 & 2 & Anodonta & kennerlyi \\
\hline $10 / 27 / 2004$ & $100-\mathrm{K}$ & $\mathrm{RC}$ & 2 & 85 & 2 & 24 & 4 & 3 & 103 & 2 & Anodonta & kennerlyi \\
\hline $10 / 27 / 2004$ & $100-\mathrm{K}$ & $\mathrm{RC}$ & 2 & 85 & 2 & 24 & 4 & 3 & 103 & 2 & Anodonta & kennerlyi \\
\hline $10 / 27 / 2004$ & $100-\mathrm{N}$ & $\mathrm{RC}$ & 2 & 101 & 2 & 21 & 3 & 3 & 145 & 2 & Anodonta & kennerlyi \\
\hline $10 / 27 / 2004$ & $100-\mathrm{N}$ & $\mathrm{RC}$ & 2 & 101 & 2 & 21 & 3 & 3 & 145 & 2 & Anodonta & kennerlyi \\
\hline $10 / 27 / 2004$ & $100-\mathrm{N}$ & $\mathrm{RC}$ & 2 & 133 & 2 & 31 & 2 & 3 & 142 & 2 & - & - \\
\hline $10 / 28 / 2004$ & Leslie Groves & IAC & 2 & 23 & 2 & 52 & 3 & 3 & - & - & Anodonta & "stumpy" \\
\hline $10 / 28 / 2004$ & Leslie Groves & IAC & 2 & 23 & 2 & 52 & 3 & 3 & - & - & Anodonta & oregonensis \\
\hline $10 / 28 / 2004$ & Leslie Groves & IAC & 2 & 23 & 2 & 52 & 3 & 3 & - & - & Anodonta & californiensis \\
\hline $10 / 28 / 2004$ & Leslie Groves & IAC & 2 & 23 & 2 & 52 & 3 & 3 & - & - & Anodonta & californiensis \\
\hline $10 / 28 / 2004$ & Leslie Groves & IAC & 2 & 23 & 2 & 52 & 3 & 3 & - & - & Anodonta & californiensis \\
\hline $10 / 28 / 2004$ & Leslie Groves & IAC & 2 & 23 & 2 & 52 & 3 & 3 & - & - & Anodonta & oregonensis \\
\hline $10 / 28 / 2004$ & Leslie Groves & IAC & 2 & 23 & 2 & 52 & 3 & 3 & - & - & Anodonta & oregonensis \\
\hline $10 / 28 / 2004$ & Leslie Groves & IAC & 2 & 23 & 2 & 52 & 3 & 3 & - & - & Anodonta & oregonensis \\
\hline $10 / 28 / 2004$ & Leslie Groves & IAC & 2 & 23 & 2 & 52 & 3 & 3 & - & - & Anodonta & oregonensis \\
\hline $10 / 28 / 2004$ & Leslie Groves & IAC & 2 & 23 & 2 & 52 & 3 & 3 & - & - & Anodonta & oregonensis \\
\hline $10 / 28 / 2004$ & Leslie Groves & IAC & 2 & 23 & 2 & 52 & 3 & 3 & - & - & Anodonta & oregonensis \\
\hline $10 / 28 / 2004$ & Leslie Groves & IAC & 2 & 23 & 2 & 52 & 3 & 3 & - & - & Anodonta & oregonensis \\
\hline $10 / 28 / 2004$ & Leslie Groves & IAC & 2 & 23 & 2 & 52 & 3 & 3 & - & - & Anodonta & kennerlyi \\
\hline $10 / 28 / 2004$ & Leslie Groves & IAC & 2 & 23 & 2 & 52 & 3 & 3 & - & - & Anodonta & kennerlyi \\
\hline $10 / 28 / 2004$ & Leslie Groves & IAC & 2 & 23 & 2 & 52 & 3 & 3 & - & - & Anodonta & kennerlyi \\
\hline $10 / 28 / 2004$ & Leslie Groves & IAC & 2 & 23 & 2 & 52 & 3 & 3 & - & - & Anodonta & kennerlyi \\
\hline $10 / 28 / 2004$ & Leslie Groves & IAC & 2 & 23 & 2 & 52 & 3 & 3 & - & - & Anodonta & kennerlyi \\
\hline $10 / 28 / 2004$ & $300-A$ & IAC & 1 & $<6$ & 1 & $<6$ & 4 & 4 & 70 & 4 & Anodonta & oregonensis \\
\hline $10 / 28 / 2004$ & Wooded island & IAC & 2 & 25 & 2 & 73 & 4 & 2 & 103 & 2 & Anodonta & kennerlyi \\
\hline $10 / 28 / 2004$ & Wooded island & IAC & 2 & 25 & 2 & 73 & 4 & 2 & 103 & 2 & Anodonta & californiensis \\
\hline $10 / 28 / 2004$ & Wooded island & IAC & 2 & 25 & 2 & 73 & 4 & 2 & 103 & 2 & Anodonta & californiensis \\
\hline $10 / 28 / 2004$ & Wooded island & IAC & 2 & 25 & 2 & 73 & 4 & 2 & 103 & 2 & Anodonta & kennerlyi \\
\hline
\end{tabular}




\begin{tabular}{|c|c|c|c|c|c|c|c|c|c|c|c|c|}
\hline \multirow[b]{2}{*}{ Date } & \multirow[b]{2}{*}{ General Area } & \multirow[b]{2}{*}{$\begin{array}{l}\text { River } \\
\text { Class }\end{array}$} & \multicolumn{6}{|c|}{ Habitat Characteristics } & \multirow[b]{2}{*}{$\begin{array}{l}\text { Transect } \\
\text { Length }(m)\end{array}$} & \multirow[b]{2}{*}{$\begin{array}{c}\text { Transect } \\
\text { Width (m) }\end{array}$} & \multicolumn{2}{|c|}{ Taxonomy } \\
\hline & & & $\begin{array}{c}\text { Dominant } \\
\text { Substrate } \\
\text { Class }(1-4)\end{array}$ & $\begin{array}{l}\text { Dominant } \\
\text { Substrate } \\
\text { Size }(\mathrm{mm})\end{array}$ & $\begin{array}{l}\text { Subdominant } \\
\text { Substrate } \\
\text { Class (1-4) }\end{array}$ & $\begin{array}{l}\text { Subdominant } \\
\text { Substrate Size } \\
(\mathrm{mm})\end{array}$ & $\begin{array}{l}\text { Embed. } \\
\text { Class (1-4) }\end{array}$ & $\begin{array}{c}\text { Aquatic } \\
\text { Vegetation } \\
\text { Class (1-4) }\end{array}$ & & & Genera & Species \\
\hline $10 / 28 / 2004$ & Wooded island & IAC & 2 & 25 & 2 & 73 & 4 & 2 & 103 & 2 & Anodonta & kennerlyi \\
\hline $10 / 28 / 2004$ & Wooded island & IAC & 2 & 25 & 2 & 73 & 4 & 2 & - & - & Anodonta & kennerlyi \\
\hline $10 / 28 / 2004$ & Wooded island & IAC & 2 & 25 & 2 & 73 & 4 & 2 & - & - & Anodonta & oregonensis \\
\hline $10 / 28 / 2004$ & Wooded island & IAC & 2 & 25 & 2 & 73 & 4 & 2 & - & - & Anodonta & "stumpy" \\
\hline $10 / 28 / 2004$ & Wooded island & IAC & 2 & 25 & 2 & 73 & 4 & 2 & - & - & Anodonta & "stumpy" \\
\hline $10 / 29 / 2004$ & White Bluffs & SBC & 1 & $<6$ & 1 & $<6$ & 4 & 3 & - & - & Anodonta & kennerlyi \\
\hline $10 / 29 / 2004$ & White Bluffs & SBC & 1 & $<6$ & 1 & $<6$ & 4 & 3 & - & - & Anodonta & californiensis \\
\hline $10 / 29 / 2004$ & White Bluffs & SBC & 1 & $<6$ & 1 & $<6$ & 4 & 3 & - & - & Anodonta & californensis \\
\hline $10 / 29 / 2004$ & White Bluffs & SBC & 1 & $<6$ & 1 & $<6$ & 4 & 3 & - & - & Anodonta & kennerlyi \\
\hline $10 / 29 / 2004$ & White Bluffs & SBC & 1 & $<6$ & 1 & $<6$ & 4 & 3 & - & - & Anodonta & oregonensis \\
\hline $10 / 29 / 2004$ & White Bluffs & SBC & 1 & $<6$ & 1 & $<6$ & 4 & 3 & - & - & Anodonta & oregonensis \\
\hline $10 / 29 / 2004$ & White Bluffs & SBC & 1 & $<6$ & 1 & $<6$ & 4 & 3 & - & - & Anodonta & kennerlyi \\
\hline $10 / 29 / 2004$ & White Bluffs & SBC & 1 & $<6$ & 1 & $<6$ & 4 & 3 & - & - & Anodonta & californensis \\
\hline $10 / 29 / 2004$ & White Bluffs & SBC & 1 & $<6$ & 1 & $<6$ & 4 & 3 & - & - & Anodonta & californensis \\
\hline $10 / 29 / 2004$ & White Bluffs & SBC & 1 & $<6$ & 1 & $<6$ & 4 & 3 & - & - & Anodonta & californensis \\
\hline $10 / 29 / 2004$ & White Bluffs & SBC & 1 & $<6$ & 1 & $<6$ & 4 & 3 & - & - & Anodonta & californiensis \\
\hline $10 / 29 / 2004$ & White Bluffs & SBC & 1 & $<6$ & 1 & $<6$ & 4 & 3 & - & - & Anodonta & californiensis \\
\hline $10 / 29 / 2004$ & White Bluffs & SBC & 1 & $<6$ & 1 & $<6$ & 4 & 3 & - & - & Anodonta & oregonensis \\
\hline $10 / 29 / 2004$ & White Bluffs & SBC & 1 & $<6$ & 1 & $<6$ & 4 & 3 & - & - & Anodonta & kennerlyi \\
\hline $10 / 29 / 2004$ & White Bluffs & SBC & 1 & $<6$ & 1 & $<6$ & 4 & 3 & - & - & Anodonta & californensis \\
\hline $10 / 29 / 2004$ & White Bluffs & SBC & 1 & $<6$ & 1 & $<6$ & 4 & 3 & - & - & Anodonta & californensis \\
\hline $10 / 29 / 2004$ & White Bluffs & SBC & 1 & $<6$ & 1 & $<6$ & 4 & 3 & - & - & Anodonta & californiensis \\
\hline $10 / 29 / 2004$ & White Bluffs & SBC & 1 & $<6$ & 1 & $<6$ & 4 & 3 & - & - & Anodonta & kennerlyi \\
\hline $10 / 29 / 2004$ & White Bluffs & SBC & 1 & $<6$ & 1 & $<6$ & 4 & 3 & - & - & Anodonta & californensis \\
\hline $10 / 29 / 2004$ & White Bluffs & SBC & 1 & $<6$ & 1 & $<6$ & 4 & 3 & - & - & Anodonta & kennerlyi \\
\hline $10 / 29 / 2004$ & White Bluffs & SBC & 1 & $<6$ & 1 & $<6$ & 4 & 3 & - & - & Anodonta & kennerlyi \\
\hline $10 / 29 / 2004$ & White Bluffs & SBC & 1 & $<6$ & 1 & $<6$ & 4 & 3 & - & - & Anodonta & californensis \\
\hline $10 / 29 / 2004$ & White Bluffs & SBC & 1 & $<6$ & 1 & $<6$ & 4 & 3 & - & - & Anodonta & oregonensis \\
\hline $10 / 29 / 2004$ & White Bluffs & SBC & 1 & $<6$ & 1 & $<6$ & 4 & 3 & - & - & Anodonta & californiensis \\
\hline $10 / 29 / 2004$ & White Bluffs & SBC & 1 & $<6$ & 1 & $<6$ & 4 & 3 & - & - & Anodonta & kennerlyi \\
\hline $10 / 29 / 2004$ & White Bluffs & SBC & 1 & $<6$ & 1 & $<6$ & 4 & 3 & - & - & Anodonta & oregonensis \\
\hline $10 / 29 / 2004$ & White Bluffs & SBC & 1 & $<6$ & 1 & $<6$ & 4 & 3 & - & - & Anodonta & californensis \\
\hline
\end{tabular}




\begin{tabular}{|c|c|c|c|c|c|c|c|c|c|c|c|c|}
\hline \multirow[b]{2}{*}{ Date } & \multirow[b]{2}{*}{ General Area } & \multirow[b]{2}{*}{$\begin{array}{l}\text { River } \\
\text { Class } \\
\end{array}$} & \multicolumn{6}{|c|}{ Habitat Characteristics } & \multirow[b]{2}{*}{$\begin{array}{c}\text { Transect } \\
\text { Length }(\mathrm{m})\end{array}$} & \multirow[b]{2}{*}{$\begin{array}{c}\text { Transect } \\
\text { Width (m) }\end{array}$} & \multicolumn{2}{|c|}{ Taxonomy } \\
\hline & & & $\begin{array}{c}\text { Dominant } \\
\text { Substrate } \\
\text { Class }(1-4)\end{array}$ & $\begin{array}{l}\text { Dominant } \\
\text { Substrate } \\
\text { Size }(\mathrm{mm})\end{array}$ & $\begin{array}{l}\text { Subdominant } \\
\text { Substrate } \\
\text { Class (1-4) }\end{array}$ & $\begin{array}{c}\text { Subdominant } \\
\text { Substrate Size } \\
(\mathrm{mm})\end{array}$ & $\begin{array}{c}\text { Embed. } \\
\text { Class (1-4) }\end{array}$ & $\begin{array}{c}\text { Aquatic } \\
\text { Vegetation } \\
\text { Class (1-4) }\end{array}$ & & & Genera & Species \\
\hline $10 / 29 / 2004$ & White Bluffs & SBC & 1 & $<6$ & 1 & $<6$ & 4 & 3 & - & - & Anodonta & kennerlyi \\
\hline $10 / 29 / 2004$ & White Bluffs & SBC & 1 & $<6$ & 1 & $<6$ & 4 & 3 & - & - & Anodonta & oregonensis \\
\hline $10 / 29 / 2004$ & White Bluffs & SBC & 1 & $<6$ & 1 & $<6$ & 4 & 3 & - & - & Anodonta & oregonensis \\
\hline $10 / 29 / 2004$ & White Bluffs & $\mathrm{SBC}$ & 1 & $<6$ & 1 & $<6$ & 4 & 3 & - & - & Anodonta & californensis \\
\hline $10 / 29 / 2004$ & White Bluffs & $\mathrm{SBC}$ & 1 & $<6$ & 1 & $<6$ & 4 & 3 & - & - & Anodonta & kennerlyi \\
\hline $10 / 29 / 2004$ & White Bluffs & SBC & 1 & $<6$ & 1 & $<6$ & 4 & 3 & - & - & Anodonta & californiensis \\
\hline $10 / 29 / 2004$ & White Bluffs & $\mathrm{SBC}$ & 1 & $<6$ & 1 & $<6$ & 4 & 3 & - & - & Anodonta & oregonensis \\
\hline $10 / 29 / 2004$ & White Bluffs & $\mathrm{SBC}$ & 1 & $<6$ & 1 & $<6$ & 4 & 3 & - & - & Anodonta & californiensis \\
\hline $10 / 29 / 2004$ & White Bluffs & SBC & 1 & $<6$ & 1 & $<6$ & 4 & 3 & - & - & Anodonta & kennerlyi \\
\hline $10 / 29 / 2004$ & White Bluffs & $\mathrm{SBC}$ & 1 & $<6$ & 1 & $<6$ & 4 & 3 & - & - & Anodonta & californensis \\
\hline $10 / 29 / 2004$ & White Bluffs & SBC & 1 & $<6$ & 1 & $<6$ & 4 & 3 & - & - & Anodonta & californiensis \\
\hline $10 / 29 / 2004$ & White Bluffs & $\mathrm{SBC}$ & 1 & $<6$ & 1 & $<6$ & 4 & 3 & - & - & Anodonta & californiensis \\
\hline $10 / 29 / 2004$ & White Bluffs & $\mathrm{SBC}$ & 1 & $<6$ & 1 & $<6$ & 4 & 3 & - & - & Anodonta & californiensis \\
\hline $10 / 29 / 2004$ & White Bluffs & $\mathrm{SBC}$ & 1 & $<6$ & 1 & $<6$ & 4 & 3 & - & - & Anodonta & californiensis \\
\hline $10 / 29 / 2004$ & White Bluffs & SBC & 1 & $<6$ & 1 & $<6$ & 4 & 3 & - & - & Anodonta & kennerlyi \\
\hline $10 / 29 / 2004$ & White Bluffs & $\mathrm{SBC}$ & 1 & $<6$ & 1 & $<6$ & 4 & 3 & - & - & Anodonta & californensis \\
\hline $10 / 29 / 2004$ & White Bluffs & $\mathrm{SBC}$ & 1 & $<6$ & 1 & $<6$ & 4 & 3 & - & - & Anodonta & kennerlyi \\
\hline $10 / 29 / 2004$ & White Bluffs & $\mathrm{SBC}$ & 1 & $<6$ & 1 & $<6$ & 4 & 3 & - & - & Anodonta & californensis \\
\hline $10 / 29 / 2004$ & White Bluffs & SBC & 1 & $<6$ & 1 & $<6$ & 4 & 3 & - & - & Anodonta & oregonensis \\
\hline $10 / 29 / 2004$ & White Bluffs & $\mathrm{SBC}$ & 1 & $<6$ & 1 & $<6$ & 4 & 3 & - & - & Anodonta & californiensis \\
\hline $10 / 29 / 2004$ & White Bluffs & SBC & 1 & $<6$ & 1 & $<6$ & 4 & 3 & - & - & Anodonta & californensis \\
\hline $10 / 29 / 2004$ & White Bluffs & $\mathrm{SBC}$ & 1 & $<6$ & 1 & $<6$ & 4 & 3 & - & - & Anodonta & californensis \\
\hline $10 / 29 / 2004$ & White Bluffs & SBC & 1 & $<6$ & 1 & $<6$ & 4 & 3 & - & - & Anodonta & oregonensis \\
\hline $10 / 29 / 2004$ & White Bluffs & $\mathrm{SBC}$ & 1 & $<6$ & 1 & $<6$ & 4 & 3 & - & - & Anodonta & oregonensis \\
\hline $10 / 29 / 2004$ & White Bluffs & $\mathrm{SBC}$ & 1 & $<6$ & 1 & $<6$ & 4 & 3 & - & - & Anodonta & californiensis \\
\hline $10 / 29 / 2004$ & White Bluffs & $\mathrm{SBC}$ & 1 & $<6$ & 1 & $<6$ & 4 & 3 & - & - & Anodonta & "stumpy" \\
\hline $10 / 29 / 2004$ & $100-\mathrm{F}$ & SBC & 2 & 80 & 2 & 18 & 4 & 3 & 200 & 4 & Anodonta & californiensis \\
\hline $10 / 29 / 2004$ & $100-\mathrm{F}$ & SBC & 2 & 80 & 2 & 18 & 4 & 3 & 200 & 4 & Anodonta & kennerlyi \\
\hline $10 / 29 / 2004$ & $100-\mathrm{F}$ & SBC & 2 & 80 & 2 & 18 & 4 & 3 & 200 & 4 & Anodonta & kennerlyi \\
\hline $10 / 29 / 2004$ & $100-\mathrm{F}$ & SBC & 2 & 80 & 2 & 18 & 4 & 3 & 200 & 4 & Anodonta & californiensis \\
\hline $10 / 29 / 2004$ & $100-\mathrm{F}$ & $\mathrm{SBC}$ & 2 & 80 & 2 & 18 & 4 & 3 & 200 & 4 & Anodonta & oregonensis \\
\hline $10 / 29 / 2004$ & $100-\mathrm{F}$ & $\mathrm{SBC}$ & 2 & 80 & 2 & 18 & 4 & 3 & 200 & 4 & Anodonta & oregonensis \\
\hline
\end{tabular}




\begin{tabular}{|c|c|c|c|c|c|c|c|c|c|c|c|c|}
\hline \multirow[b]{2}{*}{ Date } & \multirow[b]{2}{*}{ General Area } & \multirow[b]{2}{*}{$\begin{array}{l}\text { River } \\
\text { Class }\end{array}$} & \multicolumn{6}{|c|}{ Habitat Characteristics } & \multirow[b]{2}{*}{$\begin{array}{c}\text { Transect } \\
\text { Length }(\mathrm{m})\end{array}$} & \multirow[b]{2}{*}{$\begin{array}{c}\text { Transect } \\
\text { Width }(\mathrm{m})\end{array}$} & \multicolumn{2}{|c|}{ Taxonomy } \\
\hline & & & $\begin{array}{c}\text { Dominant } \\
\text { Substrate } \\
\text { Class (1-4) }\end{array}$ & $\begin{array}{c}\text { Dominant } \\
\text { Substrate } \\
\text { Size }(\mathrm{mm})\end{array}$ & $\begin{array}{c}\text { Subdominant } \\
\text { Substrate } \\
\text { Class }(1-4)\end{array}$ & $\begin{array}{l}\text { Subdominant } \\
\text { Substrate Size } \\
\quad(\mathrm{mm})\end{array}$ & $\begin{array}{c}\text { Embed. } \\
\text { Class (1-4) }\end{array}$ & $\begin{array}{c}\text { Aquatic } \\
\text { Vegetation } \\
\text { Class (1-4) }\end{array}$ & & & Genera & Species \\
\hline $10 / 29 / 2004$ & $100-\mathrm{F}$ & SBC & 2 & 80 & 2 & 18 & 4 & 3 & 200 & 4 & Anodonta & oregonensis \\
\hline $10 / 29 / 2004$ & $100-\mathrm{F}$ & $\mathrm{SBC}$ & 2 & 80 & 2 & 18 & 4 & 3 & 200 & 4 & Anodonta & californiensis \\
\hline $10 / 29 / 2004$ & $100-\mathrm{F}$ & SBC & 2 & 80 & 2 & 18 & 4 & 3 & 200 & 4 & Anodonta & kennerlyi \\
\hline $10 / 29 / 2004$ & $100-\mathrm{F}$ & SBC & 2 & 80 & 2 & 18 & 4 & 3 & 200 & 4 & Anodonta & californiensis \\
\hline $10 / 29 / 2004$ & $100-\mathrm{F}$ & SBC & 2 & 80 & 2 & 18 & 4 & 3 & 200 & 4 & Anodonta & californiensis \\
\hline $10 / 29 / 2004$ & $100-\mathrm{F}$ & $\mathrm{SBC}$ & 2 & 80 & 2 & 18 & 4 & 3 & 200 & 4 & Anodonta & kennerlyi \\
\hline $10 / 29 / 2004$ & $100-\mathrm{F}$ & $\mathrm{SBC}$ & 2 & 80 & 2 & 18 & 4 & 3 & 200 & 4 & Anodonta & californiensis \\
\hline $10 / 29 / 2004$ & $100-\mathrm{F}$ & SBC & 2 & 80 & 2 & 18 & 4 & 3 & 200 & 4 & Anodonta & kennerlyi \\
\hline $10 / 29 / 2004$ & $100-\mathrm{F}$ & $\mathrm{SBC}$ & 2 & 80 & 2 & 18 & 4 & 3 & 200 & 4 & Anodonta & californiensis \\
\hline $10 / 29 / 2004$ & $100-\mathrm{F}$ & $\mathrm{SBC}$ & 2 & 80 & 2 & 18 & 4 & 3 & 200 & 4 & Anodonta & californiensis \\
\hline $10 / 29 / 2004$ & $100-\mathrm{F}$ & $\mathrm{SBC}$ & 2 & 80 & 2 & 18 & 4 & 3 & 200 & 4 & Anodonta & californiensis \\
\hline $10 / 29 / 2004$ & $100-\mathrm{F}$ & SBC & 2 & 80 & 2 & 18 & 4 & 3 & 200 & 4 & Anodonta & californiensis \\
\hline $10 / 29 / 2004$ & $100-\mathrm{F}$ & SBC & 2 & 80 & 2 & 18 & 4 & 3 & 200 & 4 & Anodonta & kennerlyi \\
\hline $10 / 29 / 2004$ & $100-\mathrm{F}$ & $\mathrm{SBC}$ & 2 & 80 & 2 & 18 & 4 & 3 & 200 & 4 & Anodonta & kennerlyi \\
\hline $10 / 29 / 2004$ & $100-\mathrm{F}$ & $\mathrm{SBC}$ & 2 & 80 & 2 & 18 & 4 & 3 & 200 & 4 & Anodonta & kennerlyi \\
\hline $10 / 29 / 2004$ & $100-\mathrm{F}$ & $\mathrm{SBC}$ & 2 & 80 & 2 & 18 & 4 & 3 & 200 & 4 & Anodonta & californiensis \\
\hline $10 / 29 / 2004$ & Vernita & $\mathrm{RC}$ & 2 & 106 & 2 & 34 & 4 & 3 & - & - & Anodonta & oregonensis \\
\hline $10 / 29 / 2004$ & Vernita & $\mathrm{RC}$ & 2 & 106 & 2 & 34 & 4 & 3 & - & - & Anodonta & oregonensis \\
\hline $10 / 29 / 2004$ & Vernita & $\mathrm{RC}$ & 2 & 106 & 2 & 34 & 4 & 3 & - & - & Anodonta & oregonensis \\
\hline $10 / 29 / 2004$ & Vernita & $\mathrm{RC}$ & 2 & 106 & 2 & 34 & 4 & 3 & - & - & Anodonta & oregonensis \\
\hline $10 / 29 / 2004$ & Vernita & $\mathrm{RC}$ & 2 & 106 & 2 & 34 & 4 & 3 & - & - & Anodonta & oregonensis \\
\hline $10 / 29 / 2004$ & Vernita & $\mathrm{RC}$ & 2 & 106 & 2 & 34 & 4 & 3 & - & - & Anodonta & kennerlyi \\
\hline $10 / 29 / 2004$ & Vernita & $\mathrm{RC}$ & 2 & 106 & 2 & 34 & 4 & 3 & - & - & Anodonta & oregonensis \\
\hline $10 / 29 / 2004$ & Vernita & $\mathrm{RC}$ & 2 & 106 & 2 & 34 & 4 & 3 & - & - & Anodonta & oregonensis \\
\hline $10 / 29 / 2004$ & Vernita & $\mathrm{RC}$ & 2 & 106 & 2 & 34 & 4 & 3 & - & - & Anodonta & oregonensis \\
\hline $10 / 29 / 2004$ & Vernita & $\mathrm{RC}$ & 2 & 106 & 2 & 34 & 4 & 3 & - & - & Anodonta & oregonensis \\
\hline $10 / 29 / 2004$ & Vernita & $\mathrm{RC}$ & 2 & 106 & 2 & 34 & 4 & 3 & - & - & Anodonta & kennerlyi \\
\hline $10 / 29 / 2004$ & Vernita & $\mathrm{RC}$ & 2 & 106 & 2 & 34 & 4 & 3 & - & - & Anodonta & oregonensis \\
\hline $10 / 29 / 2004$ & Vernita & $\mathrm{RC}$ & 2 & 106 & 2 & 34 & 4 & 3 & - & - & Anodonta & oregonensis \\
\hline $10 / 25 / 2004$ & WSU & $\mathrm{RC}$ & 1 & $<6$ & 2 & - & 4 & 3 & 105 & 2 & Anodonta & kennerlyi \\
\hline $10 / 25 / 2004$ & WSU & $\mathrm{RC}$ & 1 & $<6$ & 2 & - & 4 & 3 & 105 & 2 & Anodonta & kennerlyi \\
\hline $10 / 25 / 2004$ & WSU & $\mathrm{RC}$ & 1 & $<6$ & 2 & - & 4 & 3 & 105 & 2 & Anodonta & californiensis \\
\hline
\end{tabular}




\begin{tabular}{|c|c|c|c|c|c|c|c|c|c|c|c|c|}
\hline \multirow[b]{2}{*}{ Date } & \multirow[b]{2}{*}{ General Area } & \multirow[b]{2}{*}{$\begin{array}{l}\text { River } \\
\text { Class }\end{array}$} & \multicolumn{6}{|c|}{ Habitat Characteristics } & \multirow[b]{2}{*}{$\begin{array}{l}\text { Transect } \\
\text { Length }(\mathrm{m})\end{array}$} & \multirow[b]{2}{*}{$\begin{array}{c}\text { Transect } \\
\text { Width (m) }\end{array}$} & \multicolumn{2}{|c|}{ Taxonomy } \\
\hline & & & $\begin{array}{c}\text { Dominant } \\
\text { Substrate } \\
\text { Class (1-4) }\end{array}$ & $\begin{array}{c}\text { Dominant } \\
\text { Substrate } \\
\text { Size }(\mathrm{mm})\end{array}$ & $\begin{array}{c}\text { Subdominant } \\
\text { Substrate } \\
\text { Class }(1-4)\end{array}$ & $\begin{array}{l}\text { Subdominant } \\
\text { Substrate Size } \\
(\mathrm{mm})\end{array}$ & $\begin{array}{c}\text { Embed. } \\
\text { Class (1-4) }\end{array}$ & $\begin{array}{c}\text { Aquatic } \\
\text { Vegetation } \\
\text { Class (1-4) }\end{array}$ & & & Genera & Species \\
\hline $10 / 25 / 2004$ & WSU & $\mathrm{RC}$ & 1 & $<6$ & 2 & - & 4 & 3 & 105 & 2 & Anodonta & kennerlyi \\
\hline $10 / 25 / 2004$ & WSU & $\mathrm{RC}$ & 1 & $<6$ & 2 & - & 4 & 3 & 105 & 2 & Anodonta & kennerlyi \\
\hline $10 / 25 / 2004$ & WSU & $\mathrm{RC}$ & 1 & $<6$ & 2 & - & 4 & 3 & 105 & 2 & Anodonta & californiensis \\
\hline $10 / 25 / 2004$ & WSU & $\mathrm{RC}$ & 1 & $<6$ & 2 & - & 4 & 3 & 105 & 2 & Anodonta & kennerlyi \\
\hline $10 / 25 / 2004$ & WSU & $\mathrm{RC}$ & 1 & $<6$ & 2 & - & 4 & 3 & 146 & 2 & Anodonta & oregonensis \\
\hline $10 / 25 / 2004$ & WSU & $\mathrm{RC}$ & 1 & $<6$ & 2 & - & 4 & 3 & 146 & 2 & Anodonta & oregonensis \\
\hline $10 / 25 / 2004$ & WSU & $\mathrm{RC}$ & 1 & $<6$ & 2 & - & 4 & 3 & 146 & 2 & Anodonta & oregonensis \\
\hline $10 / 25 / 2004$ & WSU & $\mathrm{RC}$ & 1 & $<6$ & 2 & - & 4 & 3 & 146 & 2 & Anodonta & oregonensis \\
\hline $10 / 25 / 2004$ & WSU & $\mathrm{RC}$ & 1 & $<6$ & 2 & - & 4 & 3 & 146 & 2 & Anodonta & oregonensis \\
\hline $10 / 25 / 2004$ & WSU & $\mathrm{RC}$ & 1 & $<6$ & 2 & - & 4 & 3 & 146 & 2 & Anodonta & oregonensis \\
\hline $10 / 25 / 2004$ & WSU & $\mathrm{RC}$ & 1 & $<6$ & 2 & - & 4 & 3 & 146 & 2 & Anodonta & oregonensis \\
\hline $10 / 25 / 2004$ & WSU & $\mathrm{RC}$ & 1 & $<6$ & 2 & - & 4 & 3 & 146 & 2 & Anodonta & oregonensis \\
\hline $10 / 25 / 2004$ & WSU & $\mathrm{RC}$ & 1 & $<6$ & 2 & - & 4 & 3 & 146 & 2 & Anodonta & kennerlyi \\
\hline 9/15/2004 & Leslie Groves & IAC & 2 & 65 & 1 & $<6$ & 3 & 3 & 85 & 2 & Anodonta & - \\
\hline 9/15/2004 & Leslie Groves & IAC & 2 & 65 & 1 & $<6$ & 3 & 3 & 85 & 2 & Anodonta & - \\
\hline 9/15/2004 & Leslie Groves & IAC & 2 & 65 & 1 & $<6$ & 3 & 3 & 85 & 2 & Anodonta & - \\
\hline $9 / 15 / 2004$ & Leslie Groves & IAC & 2 & 65 & 1 & $<6$ & 3 & 3 & 85 & 2 & Anodonta & - \\
\hline $9 / 15 / 2004$ & Leslie Groves & IAC & 2 & 65 & 1 & $<6$ & 3 & 3 & 85 & 2 & Anodonta & - \\
\hline $9 / 15 / 2004$ & Leslie Groves & IAC & 2 & 65 & 1 & $<6$ & 3 & 3 & 85 & 2 & Anodonta & - \\
\hline 9/15/2004 & Leslie Groves & IAC & 2 & 65 & 1 & $<6$ & 3 & 3 & 85 & 2 & Anodonta & - \\
\hline $9 / 15 / 2004$ & Leslie Groves & IAC & 2 & 65 & 1 & $<6$ & 3 & 3 & 85 & 2 & Anodonta & - \\
\hline
\end{tabular}




\section{Distribution}

No. of

Copies

\section{OFFSITE}

L Albright

U.S. Fish and Wildlife Service

64 Maple Street

Burbank, WA 99323

C Andrade

National Oceanic and Atmospheric

Administration

DARC 7600

Sandpoint Way NE

Seattle, WA 98115

J. Bartoszek

U.S. Fish and Wildlife Service

64 Maple Street

Burbank, WA 99323

G Bohnee

Nez Perce Tribe

P.O. Box 365

Lapwai, ID 83540

L Buck

Wanapum

P.O. Box 878

Ephrata, WA 98823

R Buck, Jr.

Wanapum

P.O. Box 878

Ephrata, WA 98823

L Buelow

U.S. Environmental Protection Agency

309 Bradley Boulevard

Suite 115, MS B1-46

Richland, WA 99352

L Gadbois

U.S. Environmental Protection Agency

309 Bradley Boulevard

Suite 115, MS B1-46

Richland, WA 99352
No. of

Copies
L Goldstein

Washington State Department of Ecology

P.O. Box 47600

Olympia, WA 98504

B Harper

Confederated Tribes of the Umatilla Indian

Reservation

750 Swift, Suite 14

Richland, WA 99352

S Harris

Confederated Tribes of the Umatilla Indian

Reservation

P.O. Box 638

Pendleton, OR 97801

D Landeen

Hanford Natural Resources Trustee Council

Nez Perce Tribe

P.O. Box 365

Lapwai, ID 83540

M Livingston

Washington Department of Fish and

Wildlife

2620 N. Commercial Avenue

Pasco, WA 99301

J McConnaughey

Yakama Nation

P.O. Box 6066

Kennewick, WA 99336-0066

H Newsome

Hanford Reach National Monument

U.S. Fish and Wildlife Service

64 Maple Street

Burbank, WA 99323

A Nomee

Department of Natural Resources

Coeur d'Alene Tribe

P.O. Box 408

Plummer, ID 83851-9703

Distr.1 
No. of

Copies

J Price

Washington State Department of Ecology

3100 Port of Benton Boulevard

Richland, WA 99354

M Priddy

Washington State Department of Health

309 Bradley Boulevard

Suite 201

Richland, WA 99352

P Rigdon

Yakima Nation

P.O. Box 151

Toppenish, WA 98948

P Shaffer

Oregon Department of Energy

625 Marion Street NE

Salem, OR 97301-3737

J Skriletz

Washington Department of Fish and

Wildlife

600 Capitol Way

1111 Washington Street NE

Olympia, WA 98501-1091

JA Strand

College of Science, Environmental Science

CIC 102B

WSU Tri-Cities

2710 University Drive

Richland, WA 99354-1671

BL Tiller

P.O. Box 265

Richland, WA 99352
No. of

Copies

DOE Pacific Northwest Site Office

J Erickson

K9-42

4 DOE Richland Operations Office

AR Hawkins

A5-14

KM Thompson

A6-38

DC Ward

A5-15

SR Weil

A5-15

2 Mission Support Alliance, LLC

AR Johnson

R3-12

DD Teel

H7-28

2 Washington Closure Hanford, LLC

D Jacques

$\mathrm{H} 4-22$

LC Hulstrom

H4-22

19 Pacific Northwest National Laboratory

JM Becker

K6-85

RL Dirkes

K6-75

JL Downs

K6-85

RE Durham

K6-85

DR Geist

K6-85

KD Hand

K6-85

KB Larson

K6-85

RP Mueller (5)

K6-85

TM Poston

K6-75

MR Sackschewsky

K6-85

MA Simmons

K6-85

JA Stegan

K3-66

Hanford Technical Library (2)

P8-55

Historical File - TM Poston

K6-75

\section{ONSITE}

\section{DOE Office of River Protection}

$\begin{array}{ll}\text { LA Huffman } & \text { H6-60 } \\ \text { W Russell } & \text { H6-60 }\end{array}$ 


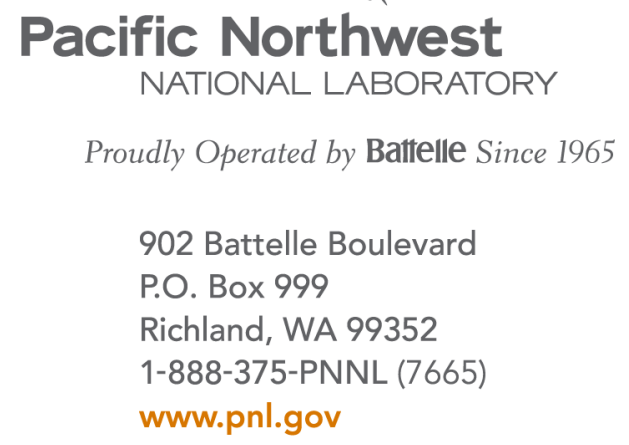

Pacific Northwest

NATIONAL LABORATORY

Proudly Operated by Battelle Since 1965

902 Battelle Boulevard

P.O. Box 999

Richland, WA 99352

1-888-375-PNNL (7665)

www.pnl.gov 